University of South Carolina

Scholar Commons

$11-2019$

\title{
The Right to Evidence of Innocence Before Pleading Guilty
}

Colin Miller

University of South Carolina - Columbia, mille933@law.sc.edu

Follow this and additional works at: https://scholarcommons.sc.edu/law_facpub

Part of the Law Commons

Recommended Citation

Colin Miller, The Right to Evidence of Innocence Before Pleading Guilty, 53 U.C. Davis L. Rev. 271, 273

(Nov. 2019).

This Article is brought to you by the Law School at Scholar Commons. It has been accepted for inclusion in Faculty

Publications by an authorized administrator of Scholar Commons. For more information, please contact

digres@mailbox.sc.edu. 


\title{
The Right to Evidence of Innocence Before Pleading Guilty
}

\author{
Colin Miller* \\ TABLE OF CONTENTS

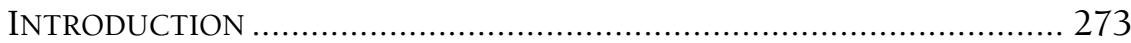

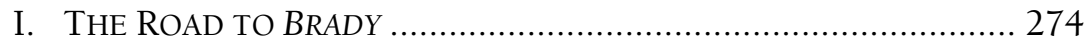

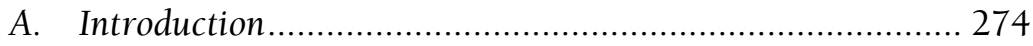

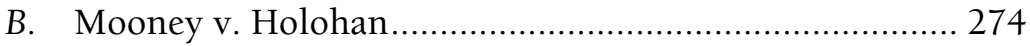

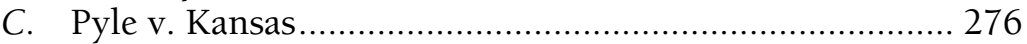

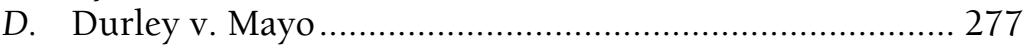

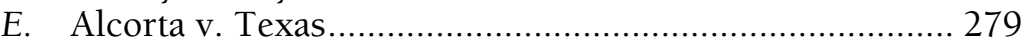 \\ F. Napue v. Illinois ......................................................... 280

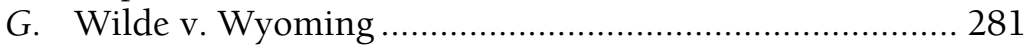

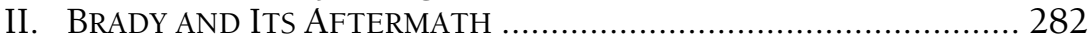

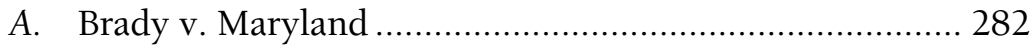

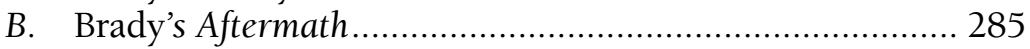 \\ 1. Giglio v. United States ........................................... 285 \\ 2. United States v. Agurs......................................... 287 \\ 3. United States v. Bagley .......................................... 288

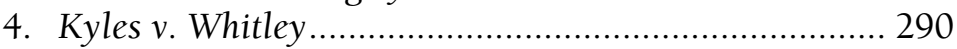 \\ 5. United States v. Ruiz................................................... 292 \\ III. RUIz'S AFTERMATH AND THE ALLEGED LACK OF A CLEAR \\ Right TO EVIDENCE OF INNOCENCE BEFORE PLEADING

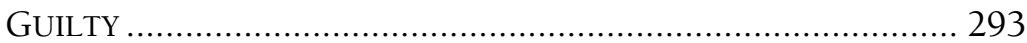

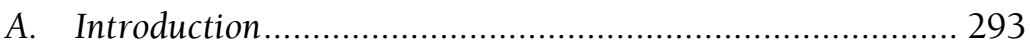 \\ B. No Distinction Between Impeachment and Substantive

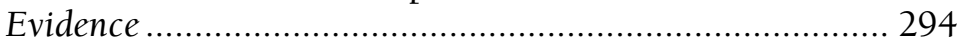 \\ C. No Established Precedent Creating a Right to Evidence of \\ Innocence Before Pleading Guilty ...................................... 295

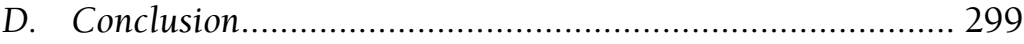 \\ * Copyright (c) 2019 Colin Miller. Professor and Associate Dean for Faculty \\ Development, University of South Carolina School of Law; Blog Editor, EvidenceProf \\ Blog: https://lawprofessors.typepad.com/evidenceprof/; Co-Host, Undisclosed Podcast: \\ http://undisclosed-podcast.com/.
}


IV. Wilde V. Wyoming CREATEd A Right to EVIDENCE of INNOCENCE BEFORE PLEADING GUILTY .................................. 299

A. Current Viability of Brady's Progenitors .......................... 299

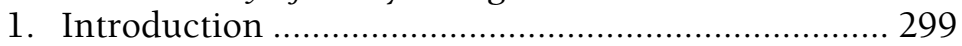

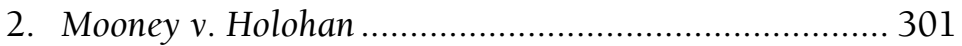

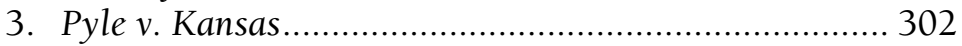

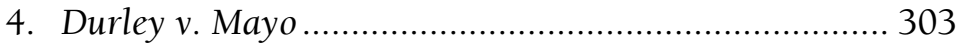

5. Alcorta v. Texas .......................................................... 305

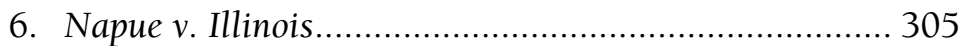

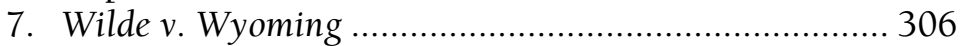

B. The Facts of the Wilde Case ........................................... 310

C. Why Wilde Should be Resuscitated .................................. 312

V. The Supreme Court Did Not RePudiate WiLDE IN RUIZ ...... 316

A. No Distinction Between Impeachment and Substantive

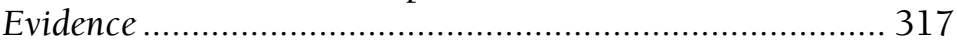

B. The Ruiz Court Did Not Repudiate Wilde ........................ 318

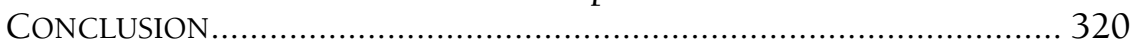




\section{INTRODUCTION}

In 2006, George Alvarez, a ninth grade, special education student, pleaded guilty to assault of a peace officer in Brownsville, Texas. ${ }^{1}$ Four years into his eight year sentence, Alvarez learned that the State had suppressed a video of the incident that proved his actual innocence. ${ }^{2}$ The video showed the officer placing Alvarez in a chokehold and a headlock while Alvarez flailed beneath him. ${ }^{3}$ Alvarez later brought an action under 42 U.S.C. Section 1983 against the City of Brownsville, claiming the city violated the Brady doctrine by failing to disclose material exculpatory evidence. In rejecting his claim in a 2018 en banc opinion, the United States Court of Appeals for the Fifth Circuit concluded that "case law from the Supreme Court, this circuit, and other circuits does not affirmatively establish that a constitutional violation occurs when Brady material is not shared during the plea bargaining process." 4 Given that around 95\% of convictions are secured through guilty pleas, ${ }^{5}$ such an interpretation of Brady means that few defendants are entitled to evidence of their innocence before being convicted.

This Article argues, however, that these courts are ignoring a largely forgotten Supreme Court opinion that was central to the creation of the Brady doctrine. In its 1960 opinion in Wilde v. Wyoming, ${ }^{6}$ the Supreme Court recognized that the suppression of favorable substantive evidence before a defendant's guilty plea can violate the Due Process Clause. Three years later, the Supreme Court stated that its opinion in Brady v. Maryland ${ }^{7}$ was merely an extension of its prior opinions such as Wilde. And yet, while each of the other opinions that formed the foundation for the Brady doctrine has had a lasting legacy, the Wilde opinion has been lost to time despite never being repudiated. This Article calls for a resurrection of the Wilde opinion and the recognition of a right to evidence of innocence before pleading guilty.

Part I discusses the Supreme Court opinions that laid the groundwork for the Brady doctrine. Part II dissects the Supreme Court's Brady opinion and subsequent Supreme Court opinions interpreting the Brady doctrine. Part III explores the split among courts over whether there is

1 Alvarez v. City of Brownsville, 904 F.3d 382, 385-88 (5th Cir. 2018).

2 See id. at 388.

3 See id.

4 Id. at 394.

5 Padilla v. Kentucky, 559 U.S. 356, 372 (2010).

6362 U.S. 607, 900-01 (1960).

7373 U.S. 83, 87 (1963). 
a pre-plea right to substantive evidence of innocence. Part IV makes the case for recognizing that Wilde recognized a clear right to evidence of innocence before pleading guilty. Finally, Part V argues that the Supreme Court did not impliedly repudiate Wilde in its opinion in United States v. Ruiz.

\section{THE ROAD TO BRADY}

\section{A. Introduction}

There were six key Supreme Court cases that the Brady Court used in creating the Brady doctrine. ${ }^{8}$ These were all cases that involved allegations that the subornation of perjury and/or the suppression of exculpatory evidence violated the Fourteenth Amendment's Due Process Clause, which states: "[N] or shall any State deprive any person of life, liberty, or property, without due process of law."9 This Part focuses on these six cases that formed the foundation for the Brady doctrine to flesh out its history and contours.

\section{B. Mooney v. Holohan}

The Supreme Court first suggested ${ }^{10}$ that the knowing subornation of perjury (i.e., a prosecutor calling a witness he knows will lie) can violate the Due Process Clause in its 1935 opinion in Mooney v. Holohan. ${ }^{11}$ In 1916, before the United States entered what became known as World War I, a pro-war rally was held near the intersection of Steuart and Market Streets in San Francisco. ${ }^{12}$ During the rally, a bomb went off at 2:06 p.m., killing nine people and injuring several others. ${ }^{13}$ Pinkerton Detective Martin Swanson soon had a suspect: "Thomas J. Mooney, a militant Socialist and labor activist, who had already been charged and acquitted several times of transporting explosives with the purpose of destroying the transmission lines of the Pacific Gas and Electric

\footnotetext{
8 See id. at 86-87.

9 U.S. CONST. amend. XIV, \& 1.

10 See, e.g., Stephen A. Saltzburg, Perjury and False Testimony: Should the Difference Matter So Much?, 68 FordHAM L. REV. 1537, 1554 (2000) ("The first case to hold that a prosecutor who knowingly used false or perjured testimony denied a defendant due process was Mooney v. Holohan.").

11 Mooney v. Holohan, 294 U.S. 103, 111-13 (1935).

12 Rebecca Roiphe, Lawyering at the Extremes: The Representation of Tom Mooney, 1916-1939, 77 FORDHAM L. REV. 1731, 1731, 1754 n.113 (2009).

13 See Ex parte Mooney, 73 P.2d 554, 557 (Cal. 1937).
} 
Company (PG\&E)." 14 The State eventually secured first-degree murder convictions and death sentences against Mooney and his alleged coconspirators. ${ }^{15}$

At the time, observers noted the lack of evidence against Mooney. ${ }^{16}$ The State's star witness was Frank Oxman, a wealthy cattleman, who was the only person "to put Mooney at the scene of explosion at the correct time." 17 Oxman testified that he had seen Mooney and his assistant place a suitcase outside a saloon near the explosion at around 1:45 p.m., with Mooney saying, "Let's go; the bulls will be after us." 18 This timing was key because Mooney was photographed at 2:01 p.m. on the roof of his apartment on Market Street between Fifth and Sixth Streets, more than a mile away from the site of the explosion; the 1:45 p.m. sighting gave "ample time for Mooney to return to his building where he had been photographed." 19

After he was convicted of murder, Mooney filed a petition for writ of habeas corpus with the United States District Court for the District of Northern California based on evidence that, inter alia, Oxman was not in San Francisco at the time of the explosion. ${ }^{20}$ Mooney's petition alleged two violations of the Fourteenth Amendment's Due Process Clause: (1) the State secured his conviction through the knowing use of perjured testimony and the deliberate suppression of impeachment evidence; and (2) the state of California failed to provide a corrective judicial process. ${ }^{21}$

Mooney's petition eventually reached the Supreme Court, which did not address Mooney's contention of suppressed evidence in its per curiam opinion. ${ }^{22}$ The Court, however, made a powerful proclamation with regard to perjured testimony. According to the Court, the requirement of due process,

cannot be deemed to be satisfied by mere notice and hearing if a State has contrived a conviction through the pretense of a trial which in truth is but used as a means of depriving a defendant of liberty through a deliberate deception of court and jury by

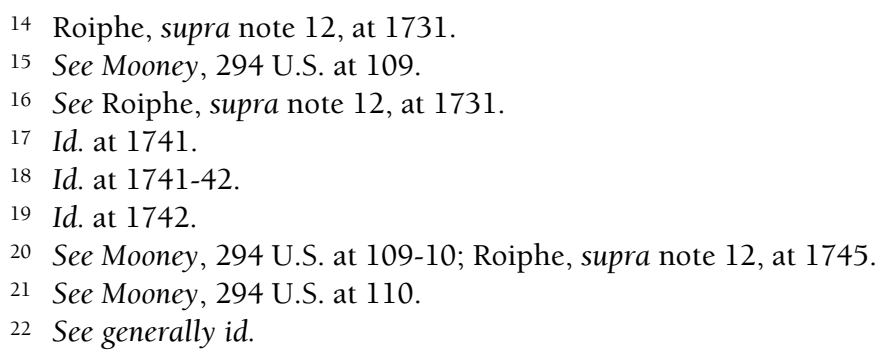


the presentation of testimony known to be perjured. Such a contrivance by a State to procure the conviction and imprisonment of a defendant is as inconsistent with the rudimentary demands of justice as is the obtaining of a like result by intimidation. ${ }^{23}$

The Court, however, found that California did provide for a corrective judicial process by allowing for writs of habeas corpus. ${ }^{24}$ Because Mooney had not applied to the state for a writ of habeas corpus, the Court denied him relief, but without prejudice. ${ }^{25}$ Mooney later filed a habeas petition in state court, with the Supreme Court of California eventually denying him relief based upon a lack of evidence that the State had suborned perjury. ${ }^{26}$ Finally, in 1937, California Governor Culbert L. Olson pardoned Mooney, claiming that he was innocent. ${ }^{27}$

The opinion of the Court in Mooney thus created the idea that the knowing subornation of perjury can violate the Due Process Clause.

\section{Pyle v. Kansas}

Seven years after its decision in Mooney, the Supreme Court addressed another allegation that a conviction was tainted by perjury in Pyle $v$. Kansas $^{28}$ in 1942. In 1934, August and Otto Reiter had $\$ 24,000$ in government bonds buried near their home outside Hudson, Kansas. ${ }^{29}$ Two days before Christmas, Harry Pyle and his son "Babe" were allegedly involved in a plan to steal the money that ended with August being fatally shot. ${ }^{30}$ After he was convicted of robbery and murder, Harry Pyle unsuccessfully brought a pro se petition for writ of habeas corpus in state court. ${ }^{31}$

Harry Pyle thereafter appealed to the United States Supreme Court, alleging a laundry list of constitutional violations. ${ }^{32}$ Specifically, he claimed that the State had (1) threatened two witnesses for the

\footnotetext{
23 Id. at 112.

24 See id. at 113.

25 See id. at 115.

26 See Ex parte Mooney, 73 P.2d 554, 596 (Cal. 1937).

27 See Roiphe, supra note 12, at 1759. Olson had previously asked Mooney to support his gubernatorial bid in exchange for a promise that his first act would be to pardon Mooney. See id.

28 Pyle v. State of Kansas, 317 U.S. 213, 214 (1942).

29 See State v. Pyle, 57 P.2d 93, 94 (Kan. 1936).

30 Id. at $96-97$.

31 See Pyle, 317 U.S. at 213-14.

32 See id. at 215-16.
} 
prosecution, including one committed to a mental institution, into testifying falsely against him; and (2) suppressed the exculpatory testimony of a husband and wife through intimidation. ${ }^{33}$ The Supreme Court cited two exhibits in support of these allegations: a letter and an affidavit by a man named Truman Reynolds, who claimed that he was forced to give perjured testimony and wrote to Harry Pyle that "Your conviction was a grave mistake." 34

The Supreme Court found that Harry Pyle's papers were inexpertly drawn but that they did "set forth allegations that his imprisonment resulted from perjured testimony, knowingly used by the State authorities to obtain his conviction, and from the deliberate suppression by those same authorities of evidence favorable to him." 35 Citing Mooney, the Court held that these allegations, if true, would establish a Constitutional violation and that they were supported by the aforementioned exhibits. ${ }^{36}$ Because there had been no legal determination of the veracity of these allegations, the Supreme Court reversed the denial of habeas relief and remanded for further proceedings. ${ }^{37}$

On remand, the Supreme Court of Kansas subsequently found that Harry Pyle had failed to prove that the State either knowingly suborned perjury or suppressed exculpatory evidence; the court therefore denied his petition for writ of habeas corpus. ${ }^{38}$ It does not appear that the elder Pyle ever received relief, but his son "Babe" was later pardoned in 1959.39

In Pyle, the Court thus built upon Mooney, suggesting that either the knowing subornation of perjury or the willful suppression of exculpatory evidence can violate the Due Process Clause.

\section{Durley v. Mayo}

Twelve years after its opinion in Pyle, the United States Supreme Court had an opportunity to address whether Mooney and Pyle applied in a case of unknowingly suborned perjury in Durley v. Mayo ${ }^{40}$ in 1956.

\footnotetext{
33 See id. at 214.

34 Id. at 215.

35 Id. at 215-16.

36 See id. at 216.

37 See id.

38 See Pyle v. Amrine, 156 P.2d 509, 518-21 (Kan. 1945).

39 See Janet Moore, Democracy and Criminal Discovery Reform After Connick and Garcetti, 77 BROOK. L. REV. 1329, 1337 n.58 (2012).

40 Durley v. Mayo, 351 U.S. 277 (1956).
} 
In 1945, Dan Durley was charged with three counts of "Horse or Cattle Stealing" based upon his alleged theft of two steers, two cows, and one heifer in Polk County, Florida. ${ }^{41}$ The only evidence linking Durley to the thefts was the testimony of Durley's alleged accomplices, R. B. Massey, Jr. and Charles Bath. ${ }^{42}$ After Durley was convicted, he filed successive petitions for relief. ${ }^{43}$ One of these was a petition for writ of habeas corpus claiming that his conviction was unconstitutional because the prosecution unknowingly suborned perjury by Massey and Bath. ${ }^{44}$

In support of his petition, Durley submitted two affidavits. ${ }^{45}$ The first affidavit was by inmate J. E. Croft, who claimed that Bath told him that Durley was "completely innocent" and that Massey and he created a plan to pin the crimes on Durley if they were caught in connection with their cattle-stealing ventures. ${ }^{46}$ The second affidavit was by Massey, who stated, "Before God is my judge Dan Durley, never had anything to do with any cattle stealing that I testified to at the trial." 47 While Durley did not allege that the State was aware that it was suborning perjury at his trial, he did claim that the State could not "let his conviction stand solely on perjured testimony." 48 The Supreme Court of Florida ultimately denied Durley relief without a hearing. ${ }^{49}$

In a majority opinion, the United States Supreme Court later concluded that it lacked jurisdiction to hear Durley's appeal because the Supreme Court of Florida's opinion may have been based on state, rather than federal, grounds.50 Justice Douglas, however, wrote a dissenting opinion that was joined by three other justices.51 After finding jurisdiction, Justice Douglas cited Mooney and Pyle for the proposition that "[i]t is well settled that to obtain a conviction by the use of testimony known by the prosecution to be perjured offends due process." 52 According to Justice Douglas, "[w] hile the petition did not allege that the prosecution knew that petitioner's codefendants were lying when they implicated petitioner, the State now knows that the

\footnotetext{
41 Id. at 278.

42 See id. at 286 (Douglas, J., dissenting).

43 See id. at 286-88.

44 See id. at 286-87.

45 See id. at 287.

46 Id.

$47 \mathrm{Id}$.

48 Id. at 288.

49 See id. at 285.

50 See id.

51 See id.

52 Id. at 290-91.
} 
testimony of the only witnesses against petitioner was false." 53 Based upon the lack of any remaining competent evidence to support Durley's conviction, Justice Douglas held that the denial of a hearing on Durley's habeas petition deprived him of due process of law. ${ }^{54}$

\section{E. Alcorta v. Texas}

The following year, in 1957, the Supreme Court addressed another allegation of suborned perjury in Alcorta v. Texas. ${ }^{55}$ In 1955, Alvaro Alcorta came home to his house at about 2:00 a.m. and saw his wife and a man named Natividad Castilleja sitting in a car in front of the house. ${ }^{56}$ Alcorta pulled out a knife and fatally stabbed his wife. ${ }^{57}$ According to Alcorta, Castilleja and his wife were kissing. ${ }^{58}$ Castilleja, however, testified that Alcorta's wife and he were just casual friends, that he had driven her home on the night in question, and that they were parked in front of the house due to engine trouble. ${ }^{59}$ Because the jury credited Castilleja's story, they found Alcorta guilty of murder and gave him a death sentence. If the jury had believed Alcorta's story that seeing his wife kissing another man sent him into a rage, they could have found him guilty of murder without malice, which carried a maximum sentence of five years of incarceration. ${ }^{60}$

Alcorta later brought a petition for writ of habeas corpus, alleging that the prosecutor in his case had knowingly suborned perjury by Castilleja. ${ }^{61}$ At the hearing on that petition, Castilleja testified that he told the prosecutor that he'd had sexual intercourse with Alcorta's wife on five or six occasions shortly before her death. ${ }^{62}$ According to Castilleja, "the prosecutor had told him he should not volunteer any information about such intercourse but if specifically asked about it to answer truthfully."63 The prosecutor subsequently admitted in testimony that he had knowingly suborned perjury by Castilleja. ${ }^{64}$

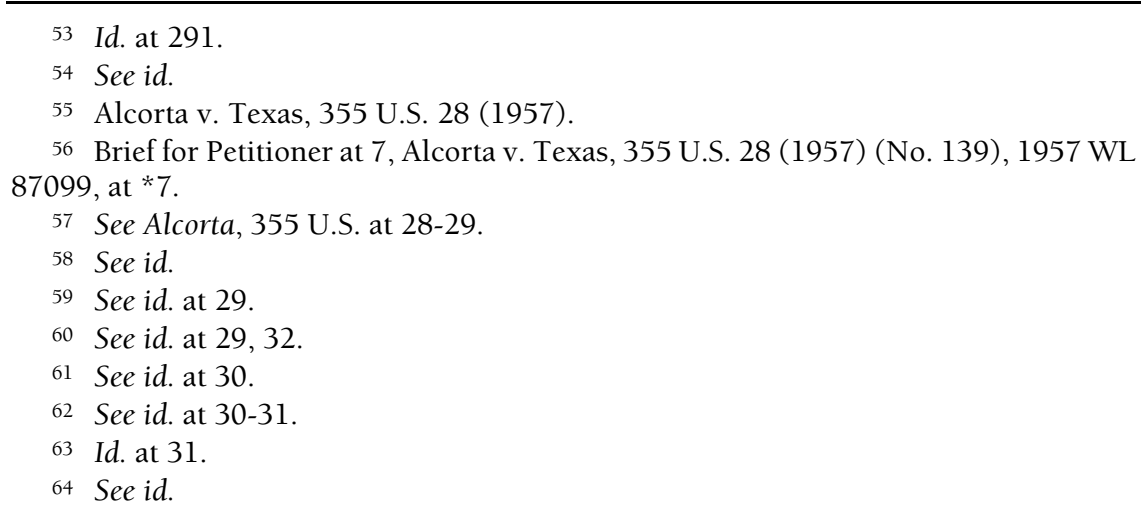


Based on this evidence, the Supreme Court held that Alcorta was denied due process under the principles laid down in Mooney and Pyle. ${ }^{65}$ The Court concluded that the perjury knowingly suborned by the prosecutor "gave the jury the false impression that [Castilleja's] relationship with [Alcorta]'s wife was nothing more than that of casual friendship." 66 Finding that in the absence of such perjury the jury might merely have found Alcorta guilty of the less serious offense of murder without malice, the Court reversed and remanded to the Court of Criminal Appeals of Texas for further proceedings. ${ }^{67}$ Following the mandate of the Supreme Court, the Court of Criminal Appeals reversed Alcorta's murder conviction. ${ }^{68}$

\section{F. Napue v. Illinois}

Two years after Alcorta, the Supreme Court further extended the holding from Mooney in its 1959 opinion in Napue v. Illinois. ${ }^{69}$ In 1938, Henry Napue and three other men allegedly entered a dimly lit Chicago lounge and announced their intention to rob it. ${ }^{70}$ An off-duty police officer responded by pulling out a gun and firing it; the officer was then killed in the ensuing shootout. ${ }^{71}$ Due to the lack of light and the passage of time before Napue was prosecuted for murder, the State relied heavily on the testimony of Napue's alleged accomplice, George Hamer, who was already serving a 199 year sentence in connection with the incident. ${ }^{72}$

At Napue's trial, Hamer testified that he was not testifying based upon a promise of consideration by the Assistant State's Attorney. ${ }^{73}$ The Assistant State's Attorney had, however, made such a promise. ${ }^{74}$ And, while the Assistant State's Attorney did not expect Hamer's false testimony, he did nothing to correct it. ${ }^{75}$ The jury was told, however,

\footnotetext{
65 See id.

66 Id.

67 See id. at 32.

68 See Alcorta v. State, 308 S.W.2d 519, 519 (Tex. Crim. App. 1957).

69 Napue v. Illinois, 360 U.S. 264, 269-72 (1959); see Brady v. Maryland, 373 U.S. 83, 87 (1963) ("In Napue v. Illinois, . . . we extended the test formulated in Mooney $v$. Holohan ....").

70 See Napue, 360 U.S. at 265.

71 See id.

72 See id. at 265-66.

73 See id. at 265.

74 See id.

75 See id.
} 
"that a public defender had promised 'to do what he could' for [Hamer]."76

Napue's post-conviction petition was eventually denied by the Supreme Court of Illinois, which found no due process violation because the jury had heard about the public defender's offer to aid Hamer. ${ }^{77}$ On appeal, the United States Supreme Court disagreed. The Court first cited Mooney, Pyle, and related cases for the proposition "that a conviction obtained through use of false evidence, known to be such by representatives of the State, must fall under the Fourteenth Amendment."78 It then cited Alcorta and related cases to conclude that "[t]he same result obtains when the State, although not soliciting false evidence, allows it to go uncorrected when it appears." 79 The Court went on to note that "[t]he principle that a State may not knowingly use false evidence, including false testimony, to obtain a tainted conviction ... does not cease to apply merely because the false testimony goes only to the credibility of the witness." 80 Instead, "[t] he jury's estimate of the truthfulness and reliability of a given witness may well be determinative of guilt or innocence, and it is upon such subtle factors as the possible interest of the witness in testifying falsely that a defendant's life or liberty may depend." 81

In March 1960, the State dismissed the charges against Napue. ${ }^{82} \mathrm{He}$ later sought compensation for his twenty years of false imprisonment, but the Illinois Court of Claims denied his request, finding that Napue hadn't proven his innocence by a preponderance of the evidence. ${ }^{83}$

\section{G. Wilde v. Wyoming}

One year after Napue was decided, in 1960, the Supreme Court issued its opinion in Wilde v. Wyoming, with petitioner Victor Donald Wilde representing himself pro se. Wilde is a short per curiam opinion, consisting of only four sentences. ${ }^{84}$ Here is the entirety of the Court's opinion:

76 Id

77 See id. at 268.

78 Id. at 269.

79 Id.

80 Id.

81 Id.

82 See Meghan Barrett Cousino, Henry Napue, NAT'L Registry of ExONERATIONS, https://www.law.umich.edu/special/exoneration/Pages/casedetailpre1989.aspx? caseid= 236. [https://perma.cc/Z92V-M9ZV] (last visited Oct. 23, 2019).

83 See id.

84 Wilde v. Wyoming, 362 U.S. 607 (1960). 
The motion for leave to proceed in forma pauperis and the petition for writ of certiorari are granted. In petitions for writ of habeas corpus, filed with the Second Judicial District Court of the State of Wyoming and with the Wyoming Supreme Court, the petitioner alleged, among other grounds for relief, that his plea of guilty to second-degree murder in December 1945, upon which he received a life sentence, was induced when he 'had no counsel present' and that the prosecutor wilfully suppressed the testimony of two eyewitnesses to the alleged crime which would have exonerated the petitioner. It does not appear from the record that an adequate hearing on these allegations was held in the District Court, or any hearing of any nature in, or by direction of, the Supreme Court. We find nothing in our examination of the record to justify the denial of hearing on these allegations. The judgment is therefore vacated and the case is remanded for a hearing thereon. Com. of Pennsylvania ex rel. Herman v. Claudy, 350 U.S. 116, 76 S.Ct. 223, 100 L.Ed. 126; Sublett v. Adams, 362 U.S. 143, 80 S.Ct. 527, 4 L.Ed.2d 527.85

Until recently, this was the only publicly available information about the Wilde case: (1) Victor Donald Wilde claimed that his guilty plea to second-degree murder was improperly induced because, inter alia, the State willfully suppressed two exculpatory eyewitness statements; and (2) the Supreme Court remanded because the Wyoming courts had not justified the denial of a hearing on Wilde's claim. But, as will be discussed infra, new documents reveal that Wilde actually created a right to evidence of innocence before pleading guilty.

\section{BRADY AND ITS AFTERMATH}

\section{A. Brady v. Maryland}

The Supreme Court finally wove together the strands of these six opinions in 1963 to create the Brady doctrine. In June 1958, John Leo Brady's sweetheart Nancy Boblit McGowan (who was married to a man named Slim) told him that she was pregnant with his child. ${ }^{86}$ To prove how much he was committed to McGowan, Brady wrote her a check for

85 Id.

86 See Thomas L. Dybdahl, An Odd, Almost Senseless Series of Events, MARSHALL PROJECT (June 24, 2018, 10:00 PM), https://www.themarshallproject.org/2018/06/24/ an-odd-almost-senseless-series-of-events. 
$\$ 35,000$ and told her, "Somehow, $\ldots$ in two weeks it'll be in the bank." 87 Brady, who was earning $\$ 1.50$ an hour at a tobacco packing company, devised a plan with McGowan's brother Donald Boblit to rob a bank in Stevensville, Maryland. ${ }^{88}$ Because Brady's 1947 Ford was unreliable, he and Boblit decided to forcibly "borrow" the Ford Fairlane belonging to acquaintance William Brooks. ${ }^{89}$ The eventual encounter ended with Brooks being fatally strangled. 90

Prior to Brady's murder trial, his attorney made a request to view all of Boblit's extrajudicial statements made in connection with the case and was shown some of these statements. ${ }^{91}$ At Brady's ensuing murder trial, Boblit testified that Brady was the one who strangled Brooks. ${ }^{92}$ At the end of that trial, Brady was convicted of first-degree murder and given the death penalty. ${ }^{93}$ After being given the death penalty, Brady appealed, claiming that the State had suppressed an unsigned statement by Boblit in which he admitted that he was the one who strangled Brooks. ${ }^{94}$ After a full hearing, the circuit court denied Brady relief. ${ }^{95}$

The Court of Appeals of Maryland later reversed, concluding that "[t]he suppression or withholding by the State of material evidence exculpatory to an accused is a violation of due process." 96 As support for this holding, Maryland's highest court cited several opinions, including two from the United States Court of Appeals for the Third Circuit. ${ }^{97}$ The first opinion was United States ex rel. Almeida v. Baldi, in which the court used Mooney and Pyle to find a due process violation based on the suppression of an exculpatory ballistics analysis of a bloody bullet found at a murder scene. ${ }^{98}$ And the second opinion was United States ex rel. Thompson $v$. Dye, in which the court found a due process violation based on the suppression of evidence of the defendant's intoxication, which could have been used to rebut the

87 Id.

88 See id.

89 See id.

90 See id.

91 See Brady v. Maryland, 373 U.S. 83, 84 (1963).

92 See Brady v. State, 174 A.2d 167, 168 (Md. 1961).

93 See Brady, 373 U.S. at 84.

94 See id.

95 See id. at 84-85.

96 Brady, 174 A.2d at 169.

97 See id. (first citing United States ex rel. Almeida v. Baldi, 195 F.2d 815 (3d Cir. 1952), and then citing United States ex rel. Thompson v. Dye, 221 F.2d 763 (3d Cir. 1955)).

98 See United States ex rel. Almeida v. Baldi, 195 F.2d 815, 820-21 (3d Cir. 1952). 
State's claim that he committed premeditated murder.99 Applying similar reasoning, the Court of Appeals of Maryland found a due process violation, concluding that Boblit's suppressed confession was material to Brady's punishment because it could have led the jury to impose a life sentence instead of a death sentence. 100

On appeal, the United States Supreme Court affirmed this ruling in Brady v. Maryland. ${ }^{101}$ The Court began by proclaiming that "[t]his ruling is an extension of Mooney $v$. Holohan," which, as noted, held that the knowing subornation of perjury violates the Due Process Clause. ${ }^{102}$ The Brady Court then observed that Pyle v. Kansas phrased this rule from Mooney "in broader terms" by concluding that allegations of knowingly suborned perjury and suppressed evidence were sufficient to charge a deprivation of rights. ${ }^{103} \mathrm{Next}$, the Court noted that the Third Circuit in the aforementioned Baldi case interpreted Pyle as holding "that the 'suppression of evidence favorable' to the accused was itself sufficient to amount to a denial of due process."104

The Supreme Court then indicated that "[i]n Napue v. Illinois ... we extended the test formulated in Mooney v. Holohan when we said: 'The same result obtains when the State, although not soliciting false evidence, allows it to go uncorrected when it appears." 105 Immediately after this citation to Napue, the Brady Court added an "And see" citation to Alcorta v. Texas and Wilde v. Wyoming as well as a "Cf." citation to the dissenting opinion in Durley v. Mayo. ${ }^{106}$ And then, immediately after citing to these three opinions, the Court created the Brady doctrine: "We now hold that the suppression by the prosecution of evidence favorable to an accused upon request violates due process where the evidence is material either to guilt or to punishment, irrespective of the good faith or bad faith of the prosecution." 107

After creating this Brady doctrine, the Court explained how it was merely an extension of Mooney and its progeny. According to the Court, " $[\mathrm{t}]$ he principle of Mooney $v$. Holohan is not punishment of society for misdeeds of a prosecutor but avoidance of an unfair trial to the

99 See United States ex rel. Thompson v. Dye, 221 F.2d 763, 766-78 (3d Cir. 1955).

100 See Brady, 174 A.2d at 171-72.

101373 U.S. 83, 90 (1963).

102 See id. at 86. Even before citing Mooney, the Court noted that the Third Circuit's opinions in Baldi and Dye had "state[d] the correct constitutional rule." Id.

103 Id.

104 Id. at 87 (citing Baldi, 195 F.2d at 820).

105 Id. (citation omitted).

106 Id.

107 Id. 
accused." 108 This is because "[s] ociety wins not only when the guilty are convicted but when criminal trials are fair; our system of the administration of justice suffers when any accused is treated unfairly." 109 Therefore, the suppression of favorable evidence, like the subornation of perjury, is a due process violation irrespective of the good faith or bad faith of the prosecution. ${ }^{110}$ Finding that Boblit's confession was favorable and material to Brady's punishment, the Supreme Court agreed with the Court of Appeals of Maryland that its suppression was a due process violation even though it was not withheld in bad faith. ${ }^{111}$

\section{B. Brady's Aftermath}

While the Supreme Court in Brady recognized an obligation for the State to disclose material exculpatory evidence, it left open a number of questions, such as when this obligation is triggered and whether it covers impeachment evidence as well as substantive evidence. Since Brady, there have been a number of Supreme Court opinions interpreting the Brady doctrine, but this Article will focus on the handful that are related to the question of whether there is a right to evidence of innocence before pleading guilty.

\section{Giglio v. United States}

In Brady, the Supreme Court found that the State's failure to disclose material substantive evidence violates the Due Process Clause. ${ }^{112}$ Substantive evidence is evidence that directly bears upon the defendant's innocence (or culpability) such as an eyewitness' identification of an alternate suspect, forensic evidence, or an alternate

\footnotetext{
108 Id.

109 Id.

110 See id. at $87-88$.

111 See id. at 86-87; see also Norman C. Bay, Old Blood, Bad Blood, and Youngblood: Due Process, Lost Evidence, and the Limits of Bad Faith, 86 WASH. U. L. REv. 241, 256 (2008) ("Under Brady and its progeny, a due process violation could be found even in the absence of bad faith."); Daniel S. Medwed, Brady's Bunch of Flaws, 67 WASH. \& LEE L. REv. 1533, 1537 (2010) ("A prosecutor's failure to abide by her disclosure obligations under Brady is not subject to a good faith exception.").

112 See, e.g., Abbott v. United States, 195 F.3d 946, 948 (7th Cir. 1999) (noting that the Supreme Court found that suppression of material substantive evidence violates the Due Process Clause in Brady and extended this holding to cover material impeachment evidence in Giglio); Colin Miller, Plea Agreements as Constitutional Contracts, 97 N.C. L. REV. 31, 67 (2018).
} 
suspect's confession. ${ }^{113}$ In its 1972 opinion in Giglio v. United States, ${ }^{114}$ the Supreme Court extended the Brady doctrine to cover material impeachment evidence, i.e., evidence that calls into question the credibility of a witness for the prosecution. ${ }^{115}$ In 1966, John Giglio allegedly concocted a scheme in which he would steal Travellers' Express money orders and give them to nineteen-year-old bank teller Robert Taliento, who would cash them so that they could share the proceeds. ${ }^{116}$ Giglio was eventually convicted of passing forged money orders based in large part upon Taliento's testimony. ${ }^{117}$ At trial, Taliento testified that nobody told him he could avoid being prosecuted if he testified against Giglio, and the Assistant U.S. Attorney ("AUSA," i.e., the federal prosecutor) told the jury that "(Taliento) received no promises that he would not be indicted." 118 Unbeknownst to the trial AUSA, the prior AUSA handling the case had told Taliento that he wouldn't be prosecuted if he testified against Giglio before the grand jury and at trial. ${ }^{119}$

Giglio's appeal of his conviction eventually reached the United States Supreme Court, which, inter alia, cited (1) Brady v. Maryland for the proposition that the State has a duty to disclose material exculpatory evidence; 120 and (2) Napue $v$. Illinois to conclude that "[w]hen the 'reliability of a given witness may well be determinative of guilt or innocence,' nondisclosure of evidence affecting credibility falls within this general rule."121 Applying this precedent to the case at hand, the Giglio Court found that the promise made by the first AUSA was attributable to the government even though the trial AUSA wasn't aware of it. ${ }^{122}$ The Court then concluded that this promise was material impeachment evidence because "the Government's case depended almost entirely on Taliento's testimony; without it there could have

\footnotetext{
113 See, e.g., State v. Coleman, 742 S.E.2d 346, 350 (N.C. Ct. App. 2013) ("It is axiomatic that in a criminal trial when substantive evidence is admitted, it bears directly upon the question of the defendant's guilt or innocence.").

114 Giglio v. United States, 405 U.S. 150 (1972).

115 See, e.g., Sterkel v. Fruehauf Corp., 975 F.2d 528, 532 (8th Cir. 1992) ("Impeachment is an attack on the credibility of a witness ....").

116 See Brief for the United States at 2-3, Giglio v. United States, 405 U.S. 150 (1972) (No. 70-29), 1971 WL 133464, at *2-3.

117 See Giglio, 405 U.S. at 151.

118 Id. at 151-52.

119 See id. at 152.

120 See id. at 153.

121 Id. at 154.

122 See id.
} 
been no indictment and no evidence to carry the case to the jury."123 Accordingly, the Giglio Court held that the non-disclosure of this promise violated the Brady doctrine. ${ }^{124}$

In United States $v$. Bagley, the Supreme Court later observed that Giglio obligates prosecutors to disclose material impeachment evidence related to key Government witnesses. ${ }^{125}$ When defendants allege that the State has failed to disclose material impeachment evidence, courts frequently use phrases such as "Giglio evidence,"126 "Giglio rule," 127 "Giglio claim,"128 and "Giglio violation."129

\section{United States v. Agurs}

In its 1976 opinion in United States v. Agurs, ${ }^{130}$ the Supreme Court again extended the Brady rule while at the same time noting that the Brady opinion had combined the Supreme Court cases preceding it to create one comprehensive rule. In Agurs, prostitute Linda Agurs fatally stabbed her john, James Sewell, with a bowie knife after he caught her emptying his wallet in their motel room. ${ }^{131}$ After Agurs was convicted of second-degree murder, she appealed, claiming that the State had suppressed evidence of Sewell's violent criminal record, which would have supported her claim of self-defense. ${ }^{132}$

In addressing Agurs's claim, the Supreme Court initially held that "[t]he rule of Brady v. Maryland... arguably applies in three quite different situations. Each involves the discovery, after trial of information which had been known to the prosecution but unknown to

123 Id. at 154-55.

124 See id. at 155

125 See United States v. Bagley, 473 U.S. 667, 676-77 (1985).

126 See, e.g., United States v. Garcia, 562 F.3d 947, 952 n.7 (8th Cir. 2009) ("However, the nondisclosure of Giglio evidence only justifies a retrial if the withheld information is deemed material.").

127 See, e.g., Smith v. Sec'y, Dept. of Corrs., 572 F.3d 1327, 1335 (11th Cir. 2009) ("Accurate statements do not violate the Giglio rule.").

128 See, e.g., Banks v. Dretke, 540 U.S. 668, 690 n.11 (2004) ("Because we conclude that Banks qualifies for relief under Brady, we need not decide whether a Giglio claim, to warrant adjudication, must be separately pleaded.").

129 See, e.g., Barwick v. State, 88 So. 3d 85, 103 (Fla. 2011) ("To demonstrate a Giglio violation, a defendant must prove that (1) the prosecutor presented or failed to correct false testimony; (2) the prosecutor knew the testimony was false; and (3) the false evidence was material.").

130 United States v. Agurs, 427 U.S. 97 (1976).

131 See id. at 99.

132 See id. at 100. 
the defense." 133 The first situation covered by the Brady rule is a case in which the prosecution suborns perjury at trial, as typified by Mooney $v$. Holohan. ${ }^{134}$ The second situation is the Brady case itself, in which the defense makes a request for specific evidence - like Brady's request all of Boblit's extrajudicial statements - and the State fails to produce material exculpatory evidence. ${ }^{135}$

The third situation, which the Court was addressing in Agurs, is one in which the prosecution fails to disclose material exculpatory evidence in response to no request for exculpatory evidence or possibly a general request for "all Brady material" or for "anything exculpatory." 136 The Agurs Court concluded that the State does have a duty to disclose exculpatory evidence in this third situation if that evidence is "material." 137 The Court then explained that evidence is material "if the omitted evidence creates a reasonable doubt that did not otherwise exist."138 Applying this standard to the case at hand, the Court reached the following conclusion:

Since the arrest record was not requested and did not even arguably give rise to any inference of perjury, since after considering it in the context of the entire record the trial judge remained convinced of [Agurs]'s guilt beyond a reasonable doubt, and since we are satisfied that his firsthand appraisal of the record was thorough and entirely reasonable, we hold that the prosecutor's failure to tender Sewell's record to the defense did not deprive respondent of a fair trial as guaranteed by the Due Process Clause of the Fifth Amendment. ${ }^{139}$

\section{United States v. Bagley}

In its 1985 opinion in United States v. Bagley, ${ }^{140}$ the Supreme Court answered the question of whether this same standard of "materiality" applies in cases in which the defense makes a specific request for impeachment evidence. In Bagley, Hughes Bagley was indicted on fifteen charges of violating various firearms and narcotics statutes. ${ }^{141}$

\footnotetext{
133 Id. at 103 (citation omitted).

134 See id.

135 See id. at 104.

136 Id. at 106.

137 Id. at 107-14.

138 Id. at 112.

139 Id. at 114

140 United States v. Bagley, 473 U.S. 667 (1985).

141 See id. at 669.
} 
Before trial, defense counsel filed a discovery motion which asked for, inter alia, "[t] he names and addresses of witnesses that the government intends to call at trial. Also the prior criminal records of witnesses, and any deals, promises or inducements made to witnesses in exchange for their testimony." 142 In response, the State disclosed, inter alia, information relating to its two principal witnesses but did not disclose any "deals, promises or inducements" that had been made to them. ${ }^{143}$

After Bagley was convicted, he appealed, claiming that the State failed to disclose that both of these witnesses had entered into a "Contract for Purchase of Information and Payment of Lump Sum Therefor." 144 These contracts each contained the following typed description of services:

That he will provide information regarding T-I and other violations committed by Hughes A. Bagley, Jr.; that he will purchase evidence for ATF; that he will cut [sic] in an undercover capacity for ATF; that he will assist ATF in gathering of evidence and testify against the violator in federal court. ${ }^{145}$

At the bottom of these contracts, "[ $\mathrm{t}]$ he figure ' $\$ 300.00$ ' was handwritten in each form on a line entitled 'Sum to Be Paid to Vendor."'146

Bagley claimed that these contracts were material impeachment evidence of incentivized testimony that the State failed to disclose in response to a specific discovery request. ${ }^{147}$ As in Agurs, the district court found that the disclosure of this impeachment evidence would not have changed the outcome at trial. ${ }^{148}$ On appeal, the Ninth Circuit disagreed, observing that "[s]tanding alone, the government's failure to produce requested Brady information is a serious due process violation." 149 The court then added that "a failure to disclose requested Brady information that the defendant could use to conduct an effective cross-examination is even more egregious because it threatens the defendant's right to confront adverse witnesses, and therefore, his right to a fair trial." 150 As a result, the court concluded "that the government's failure to provide

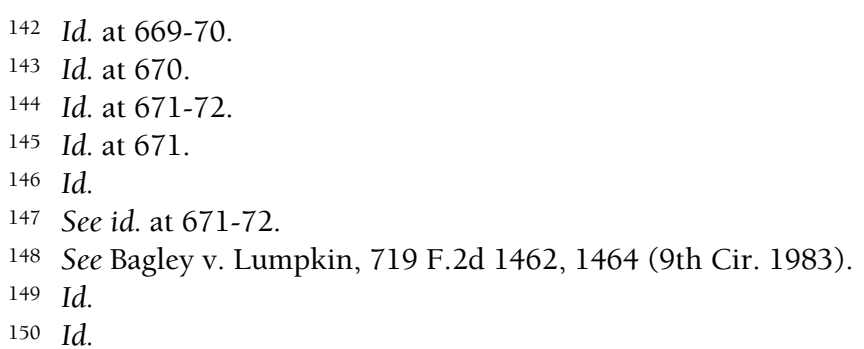


requested Brady information to Bagley so that he could effectively crossexamine two important government witnesses requires an automatic reversal." 151

The Supreme Court later disagreed with this holding. It noted that "[t]he Court of Appeals treated impeachment evidence as constitutionally different from exculpatory evidence" by holding that its non-disclosure requires automatic reversal. ${ }^{152}$ The Bagley Court rejected this reasoning, proclaiming that " $[\mathrm{t}]$ his Court has rejected any such distinction between impeachment evidence and exculpatory evidence." 153 As support, the Court cited to Giglio, in which it had required a showing of materiality before finding that the non-disclosure of impeachment evidence was a due process violation. ${ }^{154}$

The Bagley Court then added that the same test of materiality applies in "no request," "general request," and "specific request" cases: "The evidence is material only if there is a reasonable probability that, had the evidence been disclosed to the defense, the result of the proceeding would have been different."155 Put another way, "[a] 'reasonable probability' is a probability sufficient to undermine confidence in the outcome." 156 The Court then remanded the case to the United States Court of Appeals for the Ninth Circuit, which held that the suppressed contracts were material, meaning that Bagley had established a Brady violation. ${ }^{157}$

While it might have seemed relatively unimportant at the time, as will be discussed infra, the Court's comparison of impeachment and substantive evidence in Bagley has ended up playing an outsized rule in determining whether there is a right to evidence before pleading guilty.

\section{Kyles $v$. Whitley}

In its 1995 opinion in Kyles $v$. Whitley, 158 the Supreme Court (1) further clarified this materiality test; and (2) fleshed out the State's duty to discover favorable evidence that was established in Giglio. After his first trial ended in a hung jury, Curtis Lee Kyles was convicted of the first-degree murder of Dolores Dye in a New Orleans grocery store

\footnotetext{
151 Id.

152 United States v. Bagley, 473 U.S. 667, 676 (1985).

153 See id.

154 Id. at 677 (citing Giglio v. United States, 405 U.S. 150, 154 (1972)).

155 Id. at 682.

156 Id.

157 See Bagley v. Lumpkin, 798 F.2d 1297, 1302 (9th Cir. 1986).

158 Kyles v. Whitley, 514 U.S. 419 (1995).
} 
parking lot in $1984 .{ }^{159}$ Kyles subsequently appealed, claiming that the State suppressed six pieces of evidence, including exculpatory eyewitness statements and "the computer print-out of license numbers of cars parked at [the grocery store] on the night of the murder, which did not list the number of Kyles's car." 160

In finding a due process violation, the Kyles Court reached several conclusions about the Brady test, including two that will be addressed here. First, the Court held that "a showing of materiality does not require demonstration by a preponderance that disclosure of the suppressed evidence would have resulted ultimately in the defendant's acquittal."161 Thus, while a defendant must establish a reasonable probability that withheld evidence would have created a different outcome at trial, he does not have to make this showing by a preponderance of the evidence, i.e., does not have to show that it was "more likely than not" the new evidence would have produced a different outcome. ${ }^{162}$

Second, as noted, the Court in Giglio found a Brady violation based upon the trial AUSA being unaware of a promise that the prior AUSA had made to a witness for the prosecution. ${ }^{163}$ In other words, the Giglio Court placed a duty on a trial prosecutor to learn about exculpatory evidence connected to another prosecutor. ${ }^{164}$ In Kyles, the undisclosed exculpatory evidence was in the possession of the police, who had not turned it over to the prosecution. 165 Nonetheless, the Court was able to find a Brady violation by concluding "that the individual prosecutor has a duty to learn of any favorable evidence known to the others acting on the government's behalf in the case, including the police."166

Because the Court found a Brady violation, Kyles was given a new trial. ${ }^{167}$ That new trial ended in a hung jury, as did two subsequent

\footnotetext{
159 See id. at $421,423$.

160 Id. at $428-29$.

161 Id. at 434.

162 Id.

163 See supra notes 122-124.

164 See, e.g., Sarah Anne Mourer, Believe It or Not: Mitigating the Negative Effects Personal Belief and Bias Have on the Criminal Justice System, 43 HOFSTRA L. REV. 1087, 1097 (2015) ("Brady and Giglio impose on the prosecution a duty to learn and disclose to the defense all 'favorable' and 'material' information 'known to the others acting on the government's behalf in the case."').

165 See Kyles, 514 U.S. at 437.

166 Id.

167 See id. at 454.
} 
trials. ${ }^{168}$ New Orleans District Attorney Harry Connick finally dismissed the charges against Kyles in 1998, and he received $\$ 150,000$ in state compensation. ${ }^{169}$

As will be discussed infra, both of the Supreme Court's holdings in Kyles bear directly upon the questions of when and how a pre-plea right to substantive evidence of innocence might be triggered.

\section{United States v. Ruiz}

Finally, in its 2002 opinion in United States v. Ruiz, the Supreme Court limited the scope of the Giglio right to material impeachment evidence. ${ }^{170}$ In August 2009, Angela Ruiz attempted to enter the United States at the Tecate Port of Entry while driving a 1970 Mercury Cougar; inspection of the vehicle revealed 66.3 pounds of marijuana hidden inside. ${ }^{171}$ Ruiz was thereafter charged with Importation of Marijuana and offered a "fast track" plea bargain, which came with a two level downward departure under the United States Sentencing Guidelines. ${ }^{172}$ The plea agreement (1) stated that "any [known] information establishing the factual innocence of the defendant' 'has been turned over to the defendant" and "acknowledge[d] the Government's "continuing duty to provide such information;"' but (2) required that Ruiz "waiv[e] the right' to receive 'impeachment information relating to any informants or other witnesses' as well as the right to receive information supporting any affirmative defense the defendant raises if the case goes to trial." 173

Ruiz refused to sign the plea agreement and ended up pleading guilty without the benefit of a plea bargain. ${ }^{174}$ At sentencing, she unsuccessfully sought the same two-level downward departure that she would have received under the plea deal. ${ }^{175}$ Ruiz thereafter appealed, claiming that the plea bargain violated her pre-plea right to material impeachment evidence. ${ }^{176}$ The Ninth Circuit agreed, concluding that a

\footnotetext{
168 See Maurice Possley, Curtis Kyles, NAT'L Registry of ExOnERAtions, https://www.law.umich.edu/special/exoneration/Pages/casedetail.aspx? caseid=3366 [https://perma.cc/QKT6-U7KW] (last updated Oct. 28, 2015).

169 See id.

170 See United States v. Ruiz, 536 U.S. 622, 633 (2002).

171 See Brief for Respondent in Opposition to United States' Petition for Writ of Certiorari at 2, United States v. Ruiz, 536 U.S. 622 (2002) (No. 01-595).

172 See Ruiz, 536 U.S. at 625.

173 Id.

174 See id. at 625-26.

175 See id. at 626.

176 See id.
} 
guilty plea is not voluntary "unless the prosecutors first made the same disclosure of material impeachment information that the prosecutors would have had to make had the defendant insisted upon a trial."177

The Supreme Court, however, disagreed for three reasons. First, the Court noted that "impeachment information is special in relation to the fairness of a trial, not in respect to whether a plea is voluntary." 178 Second, the Court "found no legal authority embodied either in this Court's past cases or in cases from other circuits that provides significant support for the Ninth Circuit's decision"; instead, prior precedent established that courts can accept guilty pleas "despite various forms of misapprehension under which a defendant might labor." 179 Third, the Court concluded that the clause in the rejected plea agreement obligating the government to provide "any information establishing the factual innocence of the defendant" diminished the concern that, "in the absence of impeachment information, innocent individuals, accused of crimes, will plead guilty." 180

\section{RUiz'S AFTERMATH AND THE Alleged LACK OF A ClEAR Right tO EVIDENCE OF INNOCENCE BEFORE PLEADING GUILTY}

\section{A. Introduction}

The Supreme Court's opinion in Ruiz has led to a split among courts over whether defendants have a right to substantive evidence of innocence before pleading guilty. ${ }^{181}$ Courts concluding that there is no right to evidence of innocence before pleading guilty have focused on two factors while courts recognizing such a right have downplayed these two factors. The ensuing Sections will explore these factors and explain how the split has made it especially difficult for defendants in qualified immunity and federal habeas corpus actions.

177 Id. at 629.

178 Id.

179 Id. at 630.

180 Id. at 631 .

181 See, e.g., Walton v. State, 165 So. 3d 516, 524-25 (Miss. Ct. App. 2015) (citing cases from the Second, Fourth, and Fifth Circuits to support its conclusion that "[s]ince Ruiz, several cases have extended its holding to cases involving material exculpatory evidence."). See also Ion Meyn, Discovery and Darkness: The Information Deficit in Criminal Disputes, 79 BROOK. L. REv. 1091, 1102 n.35 (2014) ("There is a split regarding whether Ruiz applies only to impeachment evidence, or to any and all exculpatory evidence."). 


\section{B. No Distinction Between Impeachment and Substantive Evidence}

Courts finding no pre-plea right to substantive evidence of innocence have argued that there is no distinction between impeachment evidence and substantive evidence of innocence under Brady. Some of these courts have focused on the Bagley Court's statement that the Supreme Court "has rejected any such distinction between impeachment evidence and exculpatory evidence." 182 Other courts have alleged that Ruiz itself created no distinction between these two types of evidence. ${ }^{183}$ According to these courts, because there is no pre-plea right to impeachment evidence, there must also be no pre-plea right to substantive evidence of innocence. ${ }^{184}$

For example, in United States v. Conroy, Pamela Conroy pleaded guilty to fraud charges based upon statements she made to Federal Emergency Management Agency ("FEMA") about her home in the wake of Hurricane Katrina. ${ }^{185}$ After her guilty plea, Conroy learned about a previously undisclosed FBI interview of her friend Sandra Pierce. ${ }^{186}$ According to the FBI report on the interview, Pierce was present for Conroy's call to the FEMA representative, everything Conroy told the representative was correct, and Conroy left the conversation believing she qualified for FEMA funding. ${ }^{187}$ In finding no Brady violation, the Fifth Circuit rejected Conroy's argument that Ruiz only applies to impeachment evidence and not substantive evidence of innocence. ${ }^{188}$

182 United States v. Bagley, 473 U.S. 667, 676 (1985). In its opinion in United States v. Ruiz, 241 F.3d 1157 (9th Cir. 2001), the Ninth Circuit cited this language from Bagley, but for the opposite conclusion. The Ninth Circuit used this language to refute the State's claim "that impeachment evidence is only relevant if there is going to be a trial." Id. at 1166. The Supreme Court did not cite this language from Bagley in reversing the Ninth Circuit's opinion. See generally Ruiz, 536 U.S. 662.

183 See, e.g., United States v. Ware, No. 3:13-CR-26-GFVT-REW-1, 2016 WL 9276026 , at *6 n.6 (E.D. Ky. July 26, 2016) ("The Court finds any possible distinction, as to Ruiz, between impeachment and exculpatory evidence problematic for several reasons.").

184 See, e.g., Clark v. Lewis, No. 2:12-cv-2687 TLN GGH, 2014 WL 1665224, at *8 (E.D. Cal. Apr. 25, 2014) ("Therefore, in light of Ruiz and Bagley, whether the evidence proffered by petitioner is viewed as exculpatory or impeachment material, petitioner's Brady claim fails."); Barclay v. Chappell, No. 2:13-cv-1489 GGH P, 2014 WL 931867, at *6 (E.D. Cal. Mar. 10, 2014) (same); Ransaw v. Lucas, No. 1:09 CV 02332, 2013 WL 6179418 , at $* 7$ (N.D. Ohio Nov. 25, 2013) (agreeing with the magistrate that Bagley and Ruiz mean that there is no pre-plea right to substantive evidence of innocence).

185 See United States v. Conroy, 567 F.3d 174, 176 (5th Cir. 2009).

186 See id. at 176-77.

187 See id.

188 See id. at 179. 
According to the court, "Ruiz never makes such a distinction nor can this proposition be implied from its discussion." 189

Conversely, courts recognizing a right to evidence of innocence before pleading guilty have found that the Ruiz Court held or implied that there is a distinction between impeachment evidence and substantive evidence of innocence. For example, in Buffey v. Ballard, Joseph Buffey pleaded guilty to two counts of sexual assault and one count of robbery in West Virginia pursuant to a plea agreement. 190 Before Buffey entered his plea, the State failed to disclose that a lieutenant had reached the following conclusion regarding DNA testing: "[A]ssuming there are only two contributors (including [the victim]), Joseph Buffey is excluded as the donor of the seminal fluid identified [from the rape kit] cuttings." 191

The Supreme Court of Appeals of West Virginia found that the State's failure to disclose this evidence was a Brady violation by concluding that, if this evidence had been disclosed, (1) Buffey would neither have pleaded guilty nor been told to plead guilty; and (2) the jury would not have convicted him. ${ }^{192}$ In reaching this conclusion, the court held that "the Court in Ruiz specifically distinguished impeachment evidence from exculpatory evidence." 193 According to the Supreme Court of Appeals of West Virginia, the Ruiz "Court noted that impeachment evidence differs from exculpatory evidence because it is not 'critical information of which the defendant must always be aware prior to pleading guilty given the random way in which such information may, or may not, help a particular defendant."'194 Some state and federal courts have reached similar conclusions. ${ }^{195}$

\section{No Established Precedent Creating a Right to Evidence of Innocence Before Pleading Guilty}

Courts that have found no pre-plea right to substantive evidence of innocence have often focused on the fact that there is no established

\footnotetext{
189 Id.

190 See Buffey v. Ballard, 782 S.E.2d 204, 206 (W. Va. 2015).

191 Id. at 208.

192 See id. at 220-21.

193 Id. at 213 (emphasis omitted).

194 Id. (quoting United States v. Ruiz, 536 U.S. 622, 630 (2002)).

195 See, e.g., United States v. Ohiri, 133 F. App'x 555, 562 (10th Cir. 2005); McCann v. Mangialardi, 337 F.3d 782, 787-88 (7th Cir. 2003); Ex parte Saucedo, 576 S.W.3d 712, 716-17 (Tex. Crim. App. 2019); State v. Huebler, 275 P.3d 91, 97-98 (Nev. 2012) ("In our opinion, the considerations that led to the decision in Ruiz do not lead to the same conclusion when it comes to material exculpatory information.").
} 
precedent creating a right to evidence of innocence before pleading guilty. As noted, in the Alvarez case from the introduction, the Fifth Circuit rejected a claim that the State violated the Brady doctrine by failing to disclose an exculpatory video to a ninth grade, special education student before he pleaded guilty to assaulting a peace officer. ${ }^{196}$ And, as noted, it reached this conclusion by finding that "case law from the Supreme Court, this circuit, and other circuits does not affirmatively establish that a constitutional violation occurs when Brady material is not shared during the plea bargaining process." 197 Similarly, in United States v. Mathur, the First Circuit rejected a defendant's claim that Brady applies to the plea bargaining process, noting that "[h]e does not cite a single case standing for this novel approach but, rather, relies on authority extolling the importance of plea negotiations." 198

The alleged lack of any precedent regarding a pre-plea right to evidence of innocence has most frequently hurt defendants in two contexts. The first context is the qualified immunity context. Defendants bringing civil actions against state officials for Brady violations must overcome claims of qualified immunity by establishing that (1) the official's conduct violated a statutory or constitutional right; and (2) this right was "clearly established at the time of the challenged conduct."199 Defendants bringing such actions have difficulty establishing the second part of this test due to the lack of case law clearly establishing the pre-plea right to material exculpatory evidence.

For example, in Robertson v. Lucas, several Ohio defendants pleaded guilty to drug crimes in connection with Operation Turnaround, "a highly corrupt government investigation in which an informant, inter alia, maliciously falsely identified innocent people as participants in drug sales and stole controlled 'buy money' from DEA agents." 200 After the corrupt nature of Operation Turnaround was revealed, the prosecutor successfully moved for the dismissal of the defendants' convictions. ${ }^{201}$ The defendants then brought Section 1983 actions, claiming that the failure of various state officials to disclose material exculpatory evidence connected to Operation Turnaround before they pleaded guilty violated the Brady doctrine. ${ }^{202}$ The Sixth Circuit, however, found that these officials had qualified immunity because they

196 See Alvarez v. City of Brownsville, 904 F.3d 382, 389 (5th Cir. 2018).

197 See id. at 394.

198 United States v. Mathur, 624 F.3d 498, 506-07 (1st Cir. 2010).

199 Reichle v. Howards, 566 U.S. 658, 664 (2012).

200 Robertson v. Lucas, 753 F.3d 606, 626 (6th Cir. 2014) (Keith, J., concurring).

201 See id. at 613.

202 See id. 
"were under no clearly established obligation to disclose exculpatory Brady material to the prosecutors in time to be put to effective use in plea bargaining." 203 Other courts in qualified immunity cases have reached the same conclusion. ${ }^{204}$

The second context is the habeas context. When a defendant loses an appeal of his conviction in state court, he can file a petition for writ of habeas corpus in federal court, claiming that the state court proceedings "resulted in a decision that was contrary to, or involved an unreasonable application of, clearly established Federal law, as determined by the Supreme Court of the United States."205 Again, the alleged lack of established precedent establishing a pre-plea right to Brady evidence has hurt defendants in the habeas context.

For example, in Carter v. Hobbs, Nickol Carter pleaded guilty to robbery and related crimes and later unsuccessfully appealed his convictions in state court in Arkansas.206 Carter thereafter filed a petition for writ of habeas corpus in federal court, arguing, inter alia, that the State withheld substantive evidence of his innocence, including

(1) fingerprint reports from the crime scenes that did not match his fingerprints; (2) the lack of crime lab analysis of certain evidence recovered from the crime scenes; (3) inconsistent witness statements; (4) a DNA test from a crime-scene cigarette butt that did not match his DNA; and (5) a witness who was presented a photo lineup and identified another individual as the perpetrator. ${ }^{207}$

In denying Carter relief, the court noted that "[f]irst and foremost, Petitioner's claim fails because there is no clearly established constitutional right to the disclosure of Brady material prior to the entry

203 Id. at 621-22.

204 See, e.g., Warren v. City of Birmingham, No. 2:09-CV-1025-RRA, 2010 WL 11469568 , at $* 6$ (N.D. Ala. Aug. 13, 2010) (granting an official qualified immunity because "[t]here is a substantial question of law as to whether, at the relevant time, a police officer was on notice that he would violate a criminal defendant's due process rights by withholding materially exculpatory evidence when the criminal defendant pleads guilty rather than proceeds to trial").

20528 U.S.C. \& 2254(d)(1) (2019).

206 See Carter v. Hobbs, No. 5:10CV00346 JMM/JTR, 2013 WL 1668988, at *1 (E.D. Ark. Mar. 25, 2013).

207 Id. at *5 n. 5 . 
of a guilty plea." 208 Other courts addressing similar claims have reached the same conclusion. 209

Conversely, courts finding a clearly established pre-plea right to material exculpatory evidence have argued that Brady created such a right and that Ruiz did not circumscribe that right. For example, in United States v. Nelson, Gregory Nelson pleaded guilty to traveling from Virginia to D.C. to engage in illicit sexual contact with an undercover detective he believed to be a minor. ${ }^{210}$ Nelson's claim was that he traveled to D.C. to buy methamphetamine, a claim that was bolstered by an undisclosed email in which the detective discussed his possession of methamphetamine with Nelson. ${ }^{211}$ Upon learning that the State had documentation of this email after his plea, Nelson appealed, claiming a Brady violation. ${ }^{212}$ The United States District Court for the District of Columbia agreed with him, finding that if this evidence had been disclosed before Nelson's plea, "he would have taken his chances at trial to show that he was a drug abuser looking to score, and not someone intending to abuse a child." 213

In reaching this conclusion, the court noted that the Brady Court was not narrowly concerned about avoiding unfair trials and instead more broadly "expressed a general resolve to ensure that justice is served."214 Accordingly, "precluding a defendant from raising such a Brady claim after a guilty plea could create a risk too costly to the integrity of the system of justice to countenance...."215 Moreover, the court noted that the Ruiz Court "drew a significant distinction between impeachment and exculpatory evidence and did not decide whether a defendant is entitled to exculpatory evidence at the guilty plea stage." 216 Indeed, the court went on to find that "[i]f anything, Ruiz's discussion about the importance of the government disclosing evidence that may establish a defendant's innocence suggests that, if confronted with the issue, the

\footnotetext{
208 Id. at $* 5$.

209 See, e.g., Jones v. Bryant, 27 F. App'x. 669, 701 (7th Cir. 2001) ("The Supreme Court's decisions do not clearly establish that prosecutors must reveal exculpatory information before trial, so under $\S 2254(\mathrm{~d})(1)$ Jones is not entitled to relief on federal collateral attack.").

210 See United States v. Nelson, 979 F. Supp. 2d 123, 126 (D.D.C. 2013)

211 See id.

212 See id. at 127.

213 Id. at 135.

214 Id. at 130

215 Id.

216 Id. at 129.
} 
Supreme Court would hold that a defendant has a constitutional right to exculpatory evidence at the guilty plea stage." 217

\section{Conclusion}

In summation, some courts have held that Brady can be read as creating a pre-plea right to substantive evidence of innocence that was not circumscribed by Ruiz. Conversely, other courts have concluded that (1) neither Brady nor any other Supreme Court opinion established a pre-plea right to evidence of innocence; and (2) Ruiz can be read to foreclose any alleged right to evidence of innocence before pleading guilty.

In order to establish that there is a clear right to evidence of innocence before pleading guilty, two propositions must therefore be correct: (1) Wilde v. Wyoming created such a right; and (2) United States v. Ruiz did not circumscribe that right. The next two Parts will address these two propositions.

\section{WiLdE V. WyOMing CREATED A Right to EVIDENCE OF INNOCENCE BEFORE PLEADING GUILTY}

\section{A. Current Viability of Brady's Progenitors}

\section{Introduction}

As noted, in Brady v. Maryland, the Supreme Court stated that its new Brady doctrine was merely an "extension" of Mooney v. Holohan and its progeny. ${ }^{218}$ Commentators have picked up on this "extension" language. For example, Professor Lissa Griffin observed that the Brady "Court suggested that its decision was merely an extension of earlier decisions concerning a defendant's due process right to a fair trial, such as Mooney v. Holohan ....."219 And Professor Bennett L. Gershman classified the Brady opinion as "peculiar" because "[t]he Court suggested that its decision in Brady was merely an 'extension' of earlier decisions concerning a defendant's due process right to a fair trial." 220

\footnotetext{
217 Id. at 129 n. 4.

218 See Brady v. Maryland, 373 U.S. 83, 86-87 (1963) (noting that "[t]his ruling is an extension of Mooney," which itself was extended in subsequent opinions).

219 Lissa Griffin, Pretrial Procedures for Innocent People: Reforming Brady, 56 N.Y.L. SCH. L. REV. 969, 976 n.44 (2011).

220 Bennett L. Gershman, Reflections on Brady v. Maryland, 47 S. Tex. L. Rev. 685, 693 (2006). Professor Gershman goes on to note that those earlier opinions were Mooney, Pyle, Napue, Alcorta, Wilde, and Durley (Douglas, J., dissenting). Id. at 693 n.36.
} 
Lower courts also have honed in on this "extension" language. For example, in Drumgold v. Callahan, the First Circuit noted that "Brady was an 'extension' of a line of cases beginning with Mooney $v$. Holohan ... and Pyle v. Kansas ... in which the Supreme Court held that a state actor violates a criminal defendant's due process rights by the knowing use of perjured testimony or the deliberate suppression of evidence leading to the defendant's conviction." 221 In this sense, Brady only "broke new ground in holding that a prosecutor also violates a defendant's due process rights merely by failing to disclose material evidence in his possession that is favorable to the defendant, irrespective of the good or bad faith of the prosecutor."222

Indeed, in a piece for Federal Rules Decisions a year after Brady was decided, a federal judge observed that

[a]lthough the Supreme court in its decision treats its holding as merely an extension of its decisions in Mooney v. Holohan ... and Pyle v. State of Kansas . . defense counsel have seized upon the Brady case as a complete innovation and have made it the basis for motions prior to trial to inspect all evidence in the hands of the prosecution favorable to the accused on the issues of guilt or punishment. ${ }^{223}$

The Supreme Court eventually addressed one of these motions in its 1967 opinion in Giles v. Maryland. ${ }^{224}$ In Giles, the Court grappled with the question of whether the Brady doctrine applies in the absence of a defense request for exculpatory evidence. ${ }^{225}$ There was no majority opinion in Giles, but there was a sharp divide between Justice Fortas' opinion concurring in the judgment and Justice Harlan's dissenting opinion. Justice Fortas (1) argued that Brady had extended the Mooney line of cases by holding the suppression of favorable evidence violates due process regardless of the good faith or bad faith of the prosecution; and (2) saw "no reason to make th[is] result turn on the adventitious circumstance of a request." 226 Meanwhile, Justice Harlan could not "agree that this Court in Brady extended Mooney in any fashion."227

\footnotetext{
221 Drumgold v. Callahan, 707 F.3d 28, 38 (1st Cir. 2013).

222 Id.

223 Honorable James M. Carter, Suppression of Evidence Favorable to an Accused, 34 F.R.D. 87 (1964).

224 Giles v. Maryland, 386 U.S. 66 (1967).

225 See id. at 67-68.

226 Id. at 101-02 (Fortas, J., concurring).

227 Id. at 117 n.9 (Harlan, J., dissenting).
} 
As noted, in United States $v$. Agurs, a majority of the Court would later find that Brady does apply in the absence of a defense request for exculpatory evidence. ${ }^{228}$ In reaching this conclusion, the Agurs majority twice cited to Justice Fortas' Giles concurrence, ${ }^{229}$ seemingly corroborating his claim that Brady was merely an extension of the Mooney line of cases, with its sole innovation being to make the good faith or bad faith of the State irrelevant.

Under this reading, the Mooney line of cases takes on added importance. If Brady merely extended Mooney and its progeny, those cases are illustrations of ways in which the State can violate the Due Process Clause, even if those cases did not grant relief. Such a reading is corroborated by the Supreme Court's subsequent opinion in Agurs. As noted, the Agurs Court held that "[t] he rule of Brady v. Maryland . . . arguably applies in three quite different situations." 230 The Court then noted that the first situation involved the subornation of perjury and was typified by Mooney $v$. Holohan and also illustrated by, inter alia, Pyle v. Kansas, Alcorta v. Texas, and Napue v. Illinois. 231 This reading of these cases seems consistent with both pre-Brady and post-Brady precedent citing these opinions to find due process violations despite the differing procedural postures of these cases.

\section{Mooney v. Holohan}

As noted, Mooney v. Holohan was a per curiam opinion in which the Court denied the defendant relief but noted in dicta that the knowing subornation of perjury can violate the Due Process Clause.232 The Supreme Court has since cited Mooney ninety-nine times, and, despite the Mooney Court denying the defendant relief, courts have frequently cited Mooney to find that the knowing subornation of perjury can violate the Due Process Clause.

For instance, in its 1999 opinion in Limone v. Condon, the First Circuit denied relief to state agents seeking qualified immunity from a petitioner's claim that they knowingly suborned perjury. ${ }^{233}$ In denying

\footnotetext{
228 See United States v. Agurs, 427 U.S. 97, 109 (1976).

229 See id. at 109 n. 16, 120. The Agurs Court also noted that Brady "expressly rejected the good faith or the bad faith of the prosecutor as the controlling consideration." Id. at 110 n.17.

230 Id. at 103.

231 See id. at 103, n.8.

232 See, e.g., United States v. Ohiri, 133 F. App'x. 555, 562 (10th Cir. 2005) (finding that Ruiz's reasoning justifies distinguishing substantive evidence of innocence from impeachment evidence).

233 See Limone v. Condon, 372 F.3d 39, 43 (1st Cir. 2004).
} 
qualified immunity, the court proclaimed that Mooney created "a duty to refrain from procuring convictions by the presentation of testimony known to be perjurious. . ." 234 Indeed, the court noted that as early as 1951, it had "described Mooney's core premise as 'well-settled."'235

Courts sometimes combine the Supreme Court's opinion in Mooney with its subsequent opinion in Napue $v$. Illinois in cases involving alleged subornation of perjury to refer to a "Mooney-Napue claim" 236 or a "Mooney-Napue violation." 237 Other courts add the Supreme Court's opinion in Pyle v. Kansas to talk about the "Mooney-Pyle-Napue line of decisions." 238

\section{Pyle v. Kansas}

Courts have also continued to cite Pyle v. Kansas when presented with claims that prosecutors suborned perjury and/or suppressed material exculpatory evidence. And they have done so despite the fact that the United States Supreme Court merely remanded Henry Pyle's case to the Supreme Court of Kansas, which ultimately found neither subornation of perjury nor suppression of evidence. ${ }^{239}$ There are at least four important observations concerning these continued citations. First, as just noted, despite the Pyle Court merely remanding, courts have cited to the "Mooney-Pyle-Napue line of decisions" to find due process violations based on the subornation of perjury. ${ }^{240}$

Second, courts also cite Pyle by itself to find that the knowing subornation of perjury violates the Due Process Clause. For example, in United States ex rel. Jones $v$. Franzen, the petitioner brought a habeas petition claiming that the State knowingly suborned perjury. ${ }^{241}$ In remanding the district court's summary dismissal of the petition, the

\footnotetext{
234 Id. at 47.

235 Id. at 45 (quoting Coggins v. O'Brien, 188 F.2d 130, 138 (1st Cir. 1951)).

236 See, e.g., Morris v. Ylst, 447 F.3d 735, 743 n.7 (9th Cir. 2006) (quoting United States v. Zuno-Arce, 339 F.3d 886, 889 (9th Cir. 2003) ("For convenience, we refer to Petitioner's argument as a 'Mooney-Napue claim.'”).

237 See, e.g., United States v. Houston, 648 F.3d 806, 814 (9th Cir. 2011) ("The government's failure to correct testimony that it later learns is perjured is also a MooneyNapue violation.").

238 Ramirez v. State, 96 S.W.3d 386, 394 (Tex. App. 2002) ("This line of cases has sometimes been referred to as the Mooney-Pyle-Napue line of decisions.").

239 See Pyle v. Kansas, 317 U.S. 213, 216 (1942).

240 See, e.g., Condon, 372 F.3d at 45 (quoting Coggins v. O’Brien, 188 F.2d 130, 138 (1st Cir. 1951)).

241 See United States ex rel. Jones v. Franzen, 676 F.2d 261, 263 (7th Cir. 1982).
} 
Seventh Circuit held that "[a]s in Pyle v. Kansas ... the perjury allegation here has been neither 'refuted nor denied ...."'242

Third, even though Pyle dealt primarily with perjury and only tangentially dealt with an unsubstantiated claim of suppressed evidence, courts frequently cite it in the latter context. As the Fifth Circuit noted in United States v. DeVoe, "Pyle has been construed to mean that the 'suppression of evidence favorable' to the accused is in itself sufficient to constitute denial of due process." 243

Fourth, the Supreme Court has cited Pyle twenty-six times, including in all of its important post-Brady opinions. ${ }^{244}$

\section{Durley v. Mayo}

As noted, in Durley v. Mayo, a majority of the Supreme Court found that it lacked jurisdiction to consider Dan Durley's claim that the State's unknowing subornation of perjury violated due process. ${ }^{245}$ In his dissenting opinion however, Justice Douglas held that the denial of a hearing on Durley's habeas petition deprived him of due process of law. ${ }^{246}$ The Brady Court ultimately used a "Cf." citation in reference to this dissenting opinion. ${ }^{247}$

Given that this was merely a dissenting opinion, it is unsurprising that a majority of courts have not since found that the unknowing subornation of perjury violates due process. As the Supreme Court of New Mexico noted in Case v. Hatch, "[a] majority of the federal circuit courts require a knowing use of perjured testimony by the prosecution to find a violation of due process." 248 That said, the Supreme Court of New Mexico ended up finding that the unknowing subornation of perjury can support a due process violation after noting that Justice Douglas' dissenting opinion in Durley "would have held that '[d]eprivation of a [habeas corpus] hearing under these circumstances

\footnotetext{
242 Id. at 266.

243 United States v. DeVoe, 489 F.2d 158, 160 (5th Cir. 1974).

244 See Strickler v. Greene, 527 U.S. 263, 281 n.19 (1999); Kyles v. Whitley, 514 U.S. 419, 432 (1995); United States v. Bagley, 473 U.S. 667, 693 (1985); United States v. Agurs, 427 U.S. 97, 103 n.8 (1976); Giglio v. United States, 405 U.S. 150, 153 (1972); Giles v. Maryland, 386 U.S. 66, 73 (1967).

245 Durley v. Mayo, 351 U.S. 277, 285 (1956).

246 Id. at 290-91 (Douglas, J., dissenting).

247 Brady v. Maryland, 373 U.S. 83, 87 (1963).

248 Case v. Hatch, 183 P.3d 905, 910 (N.M. 2008).
} 
amounts ... to a denial of due process of law."'249 Similarly, the Second Circuit cited the Durley dissent to reach the same result. 250

The United States Supreme Court has never adopted the holding of the Durley dissent, but it has flirted with it twice when asked to stay executions. In Edwards v. New York, the Court was asked to stay an execution based on the claim, inter alia, that the State had unknowingly suborned perjury from the defendant's alleged accomplice. ${ }^{251}$ In denying the stay, the Court acknowledged that the Durley dissent held "that in some circumstances the innocent use of perjured testimony might involve a denial of due process." 252 But the Edwards Court ultimately found that "[t]he circumstances in Durley ... bear no resemblance to the situation presented here." 253

Later, in 1995, the Supreme Court was asked to stay the execution of Jesse Dewayne Jacobs, who confessed to fatally shooting Etta Urdiales; Jacobs' confession was read at his trial.254 The State subsequently prosecuted Jacobs' alleged accomplice, Bobbie Hogan, and called Jacobs, who testified that it was Hogan who shot Urdiales. ${ }^{255}$ Several police officers also testified "that portions of Jacobs' confession were untrue." 256 The prosecutor ultimately explained to the jury that his theory of the case had changed and that he now believed that Hogan shot Urdiales and that Jacobs "did not in any way anticipate that the victim would be shot." 257

Justices Stevens and Ginsburg dissented from the decision not to grant the stay of execution, noting that Justice Douglas' dissenting opinion in Durley would have found a due process violation based on similar facts. ${ }^{258}$ Indeed, the dissenting justices observed that "[h] ere, the facts are far stronger than in Durley, as the State itself has formally vouched for the credibility of Jacobs' recantation of his confession and police officers have testified, under oath, that parts of Jacobs' confession were false." 259

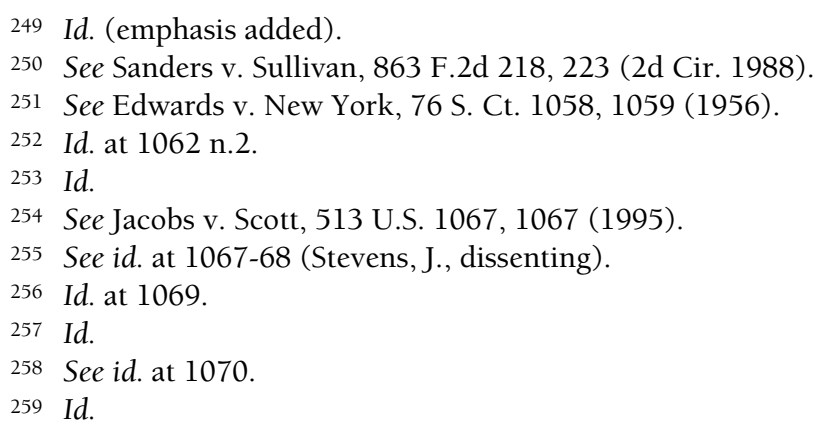




\section{Alcorta v. Texas}

Alcorta v. Texas was one of the two cases cited by the Brady Court in which a defendant was given relief. As noted, the Alcorta Court granted the defendant a new trial based upon the prosecutor's own admission that he had knowingly solicited and failed to correct false testimony by a key State's witness. ${ }^{260}$ Understandably, then, the Supreme Court has cited Alcorta eleven times, and lower courts have used Alcorta to support their findings that the knowing failure to correct false testimony is a due process violation.

For example, in Hayes v. Brown, the prosecutor "knowingly presented false evidence to the jury and made false representations to the trial judge as to whether the State had agreed not to prosecute [the defendant's accomplice] on his pending felony charges." ${ }^{261}$ In finding a due process violation, the Ninth Circuit held that "Alcorta . . involved a case quite similar to the one at bar" and compelled the finding that the prosecutor violated the Due Process Clause.262

\section{Napue v. Illinois}

Napue v. Illinois was the second case cited by the Brady Court in which a defendant was given relief. ${ }^{263}$ As noted, the Napue Court found that a prosecutor violated due process by failing to correct unexpected false testimony regarding a plea agreement by a State's witness. ${ }^{264}$ Napue has since become "the leading perjury case," 265 with the Supreme Court citing it forty times.

Lower courts have also frequently cited Napue in perjury cases. For example, in Jenkins v. Artuz, Eric Jenkins was convicted of seconddegree murder and criminal possession of a weapon. ${ }^{266}$ This conviction was secured largely through the testimony of a witness for the prosecution who falsely testified that he wasn't testifying pursuant to a plea agreement. ${ }^{267}$ In finding a due process violation, the Second Circuit cited to Napue and concluded that "[t]he case at bar presents similar

\footnotetext{
260 See Alcorta v. Texas, 355 U.S. 28, 31-32 (1957).

261 See Hayes v. Brown, 399 F.3d 972, 978 (9th Cir. 2005).

262 Id. at 983; cf. United States v. MacDonald, 778 F. Supp. 1342, 1354-55 (E.D. N.C. 1991) (examining Alcorta, 355 U.S. 28).

263 See Napue v. Illinois, 360 U.S. 264 (1959).

264 See id. at 272.

265 State v. Ayo, 7 So. 3d 85, 98 (La. Ct. App. 2009).

266 See Jenkins v. Artuz, 294 F.3d 284, 289 (2d Cir. 2002).

267 See id. at 293.
} 
facts" because Jenkins' prosecutor also did not correct the witness' false testimony. ${ }^{268}$

\section{Wilde v. Wyoming}

As noted, in Wilde $v$. Wyoming, the Supreme Court remanded a defendant's claim that he was induced into pleading guilty to seconddegree murder based on the suppression of two eyewitness statements and the denial of his right to counsel. ${ }^{269}$ As in Pyle v. Kansas, the Supreme Court remanded the case for further proceedings to determine whether there was a due process violation. ${ }^{270}$

In the fourteen years after Wilde was issued, courts cited the case twelve times. For example, in 1962, the Court of Appeals of Maryland remanded a decision denying postconviction relief to a petitioner who claimed that the State suppressed material exculpatory evidence. ${ }^{271}$ The court largely based the decision to remand on prior precedent holding that "the suppression by the State of evidence tending to exculpate a defendant is a ground for relief." 272 That prior precedent was two cases: Wilde v. Wyoming and the Court of Appeals' own prior opinion in Brady v. State, ${ }^{273}$ which was later affirmed in Brady v. Maryland. 274

A couple of years later, in 1964, the United States Court of Appeals for the Second Circuit relied upon Wilde to reverse a robbery conviction based upon the State's suppression of two exculpatory statements by eyewitnesses. ${ }^{275}$ In granting the defendant relief, the court noted the similarity between the case at hand and Wilde, where an evidentiary hearing was granted based on the petitioner's allegation "that the prosecutor wilfully suppressed the testimony of two eyewitnesses to the alleged crime which would have exonerated the petitioner." 276

\footnotetext{
268 Id.

269 See Wilde v. Wyoming, 362 U.S. 607, 607 (1960) (per curiam).

270 See id.

271 See Strosnider v. Warden of Md. Penitentiary, 180 A.2d 854, 856-57 (Md. 1962).

272 Id. at 856 (citations omitted).

273 See Brady v. State, 174 A.2d 167, 169-72 (Md. 1961) ("The suppression or withholding by the State of material evidence exculpatory to an accused is a violation of due process.").

274 See Brady v. Maryland, 373 U.S. 83, 87 (1963) ("We now hold that the suppression by the prosecution of evidence favorable to an accused upon request violates due process where the evidence is material either to guilt or to punishment, irrespective of the good faith or bad faith of the prosecution.").

275 See United States ex rel. Meers v. Wilkins, 326 F.2d 135, 135-36, 138, 140 (2nd Cir. 1964).

276 Id. (quoting Wilde v. Wyoming, 362 U.S. 607, 607 (1960)).
} 
During this stretch of fourteen years, courts would often cite Wilde and Pyle in conjunction as the pre-Brady cases standing for the proposition that the suppression of favorable evidence can violate due process. ${ }^{277}$ The Seventh Circuit was the last court to cite Wilde during this fourteen-year stretch, in its 1974 opinion in Christman v. Hanrahan. ${ }^{278}$ In Christman, the court traced the history of the Brady doctrine, noting how the Brady Court started by citing to Mooney v. Holohan and then created the Brady doctrine "[a]fter reviewing later cases in which it is fair to state that the entire proceedings were fundamentally unfair": Pyle v. Kansas, Napue v. Illinois, Alcorta v. Texas, and Wilde v. Wyoming. ${ }^{279}$

But then, the Wilde opinion disappeared. Between 1975 and 2016, not a single court cited Wilde. This streak was finally broken in December 2017, when the Court of Criminal Appeals of Alabama collaterally quoted Wilde as part of a block quote to Brady. ${ }^{280}$ Wilde's four-decade absence from court opinions is surprising given that both defendants and the State continue to cite it in their briefs. Most recently, last year, an appellant convicted of murder cited to Wilde in his brief to the Supreme Court of Florida to establish his claim that the suppression of material exculpatory evidence constituted a Giglio violation. ${ }^{281}$ A year earlier, a defendant cited Wilde in support of a claim to the Fourth Circuit that the State violated the Brady doctrine by withholding an alternate suspect's confession. ${ }^{282}$ Meanwhile, states have even cited to

277 See, e.g., United States v. Mayersohn, 452 F.2d 521, 526 (2nd Cir. 1971) (citing Pyle and Wilde for the proposition "that the suppression of evidence is a violation of due process."); United States v. Soblen, 203 F. Supp. 542, 562 (S.D.N.Y. 1961) (citing Pyle and Wilde the proposition that "[a] new trial or a writ in the nature of habeas corpus or coram nobis will be granted where the prosecutor has deliberately suppressed material facts under circumstances amounting to fraud or overreaching of the defendant.").

278500 F.2d 65, 67 n.1 (7th Cir. 1974).

279 Id. at 67.

280 See State v. Martin, CR-15-0664, 2017 WL 6398318, at *17 (Ala. Crim. App. Dec. 15, 2017), rev'd sub nom. Ex parte State, No. 1170407, 2018 WL 4177525 (Ala. Aug. 31, 2018).

281 See Initial Brief of Appellant, Thomas v. State, 260 So.3d 226 (Fla. 2018) (No. SC18-48), 2018 WL 2740354, at *54 n.39 ("In Wilde v. Wyoming, 362 U.S. 607 (1960), the validity of a guilty plea was called into question in part because of the allegation that "the prosecutor willfully suppressed the testimony of two eyewitnesses to the alleged crime which would have exonerated the petitioner."').

282 See Informal Brief for Habeas and Section 2255 Cases, United States v. Gibbs, 690 F. App'x 130 (4th Cir. 2017) (mem.) (No. 17-6135), 2017 WL 971760, at *11-12 (citing Wilde in support of a claim that the State violated the Brady doctrine by withholding an alternate suspect's confession). 
Wilde to argue that the evidence it suppressed was less exculpatory than the evidence in Wilde. 283

Defendants have also continued to cite Wilde in support of claims that the pre-plea suppression of favorable substantive evidence violates the Brady doctrine. For example, in 2013, Alan Combs cited Wilde in his brief to the Supreme Court of Washington to claim that the State violated the Brady doctrine by suppressing favorable fingerprint evidence prior to his nolo contendere plea.284 And, in 1992, Douglas Thomas used Wilde in his brief to the Supreme Court of Virginia to support his claim that the State committed a Brady violation by suppressing evidence that could have supported an involuntary intoxication defense prior to his guilty plea. ${ }^{285}$ Neither of these courts, however, ended up addressing Wilde or even the merits of either defendant's Brady claim. ${ }^{286}$ Instead, as noted, no court cited Wilde between 1975 and 2016.

So, how did Wilde go from being cited next to its Brady peers as late as 1974 to being relegated to the dustbin of history? There's no clear answer. One possibility comes in the form of the Supreme Court's 1976 opinion in United States v. Agurs. ${ }^{287}$ In Agurs, the Court created a kind of unified theory of Brady, finding that it applied in "three quite different situations." 288 One situation was the Agurs case itself, with the State suppressing exculpatory evidence that wasn't requested (or specifically requested) by the defense.289 Another situation is the suppression of exculpatory evidence requested by the defense, which the Agurs Court illustrated solely through the Brady case. ${ }^{290}$ Finally, the other situation is the subornation of perjury, which the Agurs Court

283 See, e.g., Reply Brief of Appellant, Angelone v. Dabney, 560 S.E.2d 253 (Va. 2002) (No. 011069), 2001 WL 34899214, at*4-5 (reply brief by the State claiming that the petitioner had not presented the same type of suppressed exculpatory evidence as the petitioner in Wilde).

284 See Appellants Opening Brief, Combs v. State, 311 P.3d 443 (Mont. 2013) (No. DA 12-0392), 2012 WL 5024989, at *i, iv.

285 See Opening Brief, Thomas v. Commonwealth, 419 S.E.2d 606 (Va. 1992) (No. 911850), 1992 WL 12157503, at *20-23.

286 See Combs v. State, 311 P.3d 443 (Mont. May 28, 2013) (unpublished); Thomas v. Commonwealth, 419 S.E.2d 606 (Va. 1992), abrogated by Haugen v. Shenandoah Valley Dep't of Soc. Servs., 645 S.E.2d 261 (Va. 2007). In Thomas, the Supreme Court of Virginia handled the defendant's claim as a claim of destruction of evidence under Arizona v. Youngblood, 488 U.S. 51 (1988), rather than a claim of suppression of evidence under Brady. Thomas, 419 S.E.2d at 615.

287 See United States v. Agurs, 427 U.S. 97 (1976).

288 Id. at 103-06.

289 See id. at 106-07.

290 See id. at 104-06. 
noted was typified by seven cases, including Mooney v. Holohan, Pyle v. Kansas, Alcorta v. Texas, and Napue v. Illinois. 291

One theory is that courts consulted Agurs rather than Brady in subsequent cases, explaining Wilde's omission from later opinions because Wilde was not cited in Agurs. This theory finds some support in precedent. About a month after Agurs, the Court of Criminal Appeals of Oklahoma did not mention Wilde but (1) noted that Agurs clarified the Brady doctrine; and (2) cited the same opinions cited in Agurs in adjudicating a defendant's claim that the State violated "the doctrine enunciated in Brady v. Maryland." 292 Later that same year, an appellate court in Illinois traced the history of the Brady doctrine from Mooney through Pyle, Alcorta, and Napue, omitting Wilde. ${ }^{293}$ Then, the next year, the Supreme Court of Colorado noted that "[i]n a long line of cases, the United States Supreme Court has ruled that the suppression of material evidence, favorable to the defendant and relating either to guilt or punishment, is a denial of due process which requires reversal of a conviction." 294 That "long line" again omitted Wilde but included Mooney, Pyle, Alcorta, Napue, Brady, and "[t] he Supreme Court's latest pronouncement on this subject i[n] United States v. Agurs." 295 It thus seems plausible that the Agurs Court's failure to cite Wilde led to its banishment.

Another possible explanation is the lack of available information about the Wilde case. As noted, until recently, the only publicly available information about Wilde was the Supreme Court's one paragraph per curiam opinion, which reveals next to nothing about the facts of the case. And, as noted in the last several Subsections, courts frequently cite the other Supreme Court cases referenced in Brady to resolve disputes involving analogous factual contexts. ${ }^{296}$ In the absence of a factual record in Wilde, such analogies are difficult. Additionally, without further facts, it is difficult to tell whether the suppression allegation in Wilde was a major or minor part of the petitioner's claim.

To answer pertinent questions about Wilde, I tracked down twentytwo pages of documents connected to the case that had been

291 See id. at 103-04.

292 McDonald v. State, 553 P.2d 171, 176, 179 (Okla. Crim. App. 1976).

293 See People v. Payne, 358 N.E.2d 409, 410-11 (Ill. App. Ct. 1976).

294 People v. Roblas, 568 P.2d 57, 59 (Colo. 1977).

295 Id. at 59-60.

296 See supra Parts IV.A.2-7. 
sequestered in the Wyoming State archives. 297 These pages establish the centrality of the suppression claim and the importance of Wilde in the creation of the Brady doctrine.

\section{B. The Facts of the Wilde Case}

As the newly discovered documents make clear, in his pro se petition for writ of habeas corpus, Victor Donald Wilde alleged the following: A stranger named Henry Wallace approached him at a bus station in Madison, Nebraska. 298 Wallace was driving to California and looking for paying passengers. ${ }^{299}$ Wilde, who was seeking to visit his mother in California, agreed to accompany Wallace, pay half the expenses, and share the driving load. ${ }^{300}$ Upon starting their trip, the two men picked up two young hitchhikers in their late teens. ${ }^{301}$ Around midnight, the four men checked into a motel room in eastern Wyoming with two beds. ${ }^{302}$ Wilde shared a bed with Wallace, who made "indecent advances in a homosexual manner" that Wilde rebuffed, prompting some words between the two men. ${ }^{303}$

The next day, Wallace bought and drank nearly three pints of whiskey; "as Wallace progressed in his drinking, his temper and disposition became meaner." 304 Wallace kept harping on the incident from the prior night, prompting Wilde to become disgusted and ask to be let out of the car. ${ }^{305}$ However, Wallace continued driving for another fifteen to twenty minutes while muttering under his breath before jamming on the brakes and pulling over to the side of the road. 306

Wallace then exited the car and opened the passenger door, leading to Wilde falling out of the car. ${ }^{307}$ Before Wilde could "right himself,"

\footnotetext{
297 A compendium of these documents can be viewed at Appendix to Colin Miller, The Right to Evidence of Innocence Before Pleading Guilty, available online at https://lawreview.law.ucdavis.edu/files/53-1_Miller_Appendix.pdf [hereinafter Appendix].

298 Affidavit in Support of Petition for Writ of Habeas Corpus at 3, Wilde v. Wyoming, No. 7239 (Wyo. 1959), Miller, reprinted in Miller, Appendix, supra note 297, at 8 .

299 Id.

300 Id.

301 Id.

302 Id.

303 Id.

304 Id.

305 Id.

306 Id.

307 Id. at 3-4, Miller, reprinted in Miller, Appendix, supra note 297, at 8-9.
} 
Wallace began attacking him. ${ }^{308}$ Wilde, however, got the better of Wallace, knocking him down four to five times. ${ }^{309}$ Wilde saw Wallace stumbling to the front seat of the car and thought that he had given up. ${ }^{310}$ Upon turning around to look for a resting spot, Wilde "heard a warning shout from the car." 311 It was the hitchhikers warning Wilde that Wallace had a gun. When Wilde turned around, he "was facing a wildly infuriated Wallace who definitely had the look of murder about him." 312 Wilde, who carried a gun on him, "instinctively drew and fired without thinking," killing Wallace. ${ }^{313}$

The hitchhikers and Wilde then got Wallace's body into the car and drove to a gas station because the gas tank was close to empty. ${ }^{314}$ While Wilde was filling up the car, the hitchhikers ran away. ${ }^{315}$ Wilde then drove the car toward a sheriffs station, but the car went off an icy highway, which is where a sheriff's posse arrested him. ${ }^{316}$

Wilde was later charged with first-degree murder. 317 He had two appointed attorneys, one of whom might have been named Ivan Jones. ${ }^{318}$ After Wilde told his story to his attorneys, they responded that it was a clear case of self-defense. ${ }^{319}$ Thereafter, however, Wilde was left alone in county jail for twenty days. ${ }^{320}$ Eventually, the sheriff came and asked if he would plead guilty to second-degree murder because otherwise he would be convicted of first-degree murder and be given the death penalty. ${ }^{321}$

Wilde asked to see his attorneys and was told he couldn't see them unless he went to court. Wilde agreed and saw one of his attorneys, who told him he would not represent him unless Wilde paid him $\$ 1,500$, which would lead to Wilde not serving a day in prison. ${ }^{322}$ When Wilde refused, his attorney told him to plead guilty to second-degree

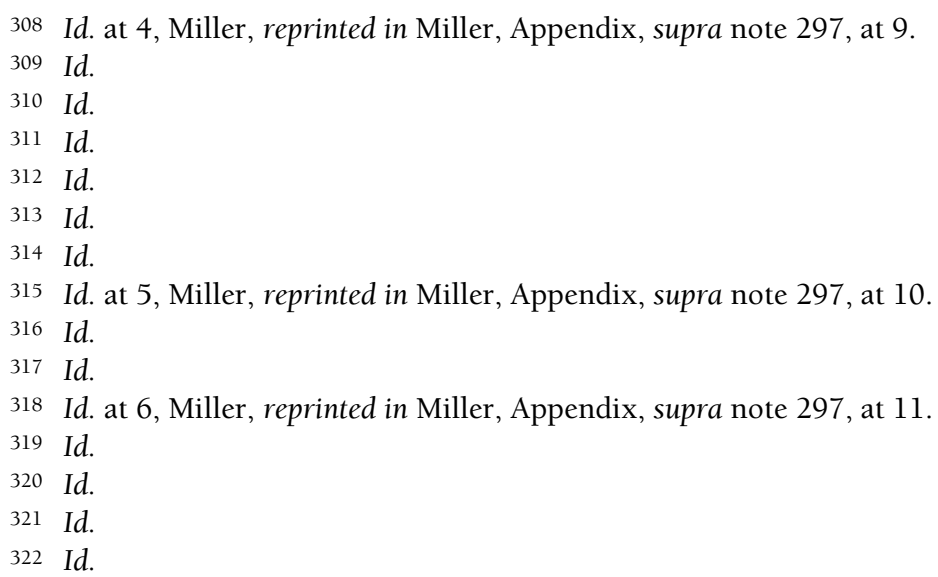


murder. ${ }^{323}$ Without his attorney present, Wilde entered the judge's chamber on December 13, 1945 and pleaded guilty to second-degree murder, resulting in him being given a life sentence. ${ }^{324}$

In his habeas petition, Wilde alleged several errors. First and foremost, Wilde claimed that the State (1) suppressed exculpatory statements by the hitchhikers that would have proven his claim of selfdefense; and (2) intimidated the hitchhikers into making false statements against him at the coroner's jury. ${ }^{325}$ Second, while Wilde admitted that he met with attorneys twice, he alleged that he was deprived of his right to counsel by not having an attorney present when he pleaded guilty. ${ }^{326}$ Third, Wilde made various other claims such as the denial of his right to a grand jury and being given an illegal sentence of "natural life" when the statute authorized a sentence of twenty years to life. ${ }^{327}$

In its answer, the State curtly responded that Wilde "was properly represented by counsel, that in all instances he had the benefit of due process of law, and none of his constitutional rights were invaded or denied." 328 The court's order denying Wilde's petition and a hearing on his petition was equally short, with the court quickly responding that "Victor Donald Wilde is legally detained in custody." 329

\section{Why Wilde Should be Resuscitated}

Obviously, the facts alleged by Wilde should be taken with a grain of salt, and it would be nice to hear the State's version of events. But the lack of the State's version is also kind of the point. The Supreme Court remanded because neither the State nor the Wyoming courts had refuted Wilde's allegations, ${ }^{330}$ which principally related to the suppression of statements by the hitchhikers. ${ }^{331}$ The Court also remanded on the issue of the denial of the right to counsel, 332 but this 
was not based on the total denial of that right but instead just denial of that right at the moment of pleading. ${ }^{333}$ Notably, the Court did not remand on Wilde's other allegations, implying that it highlighted the suppression and counsel claims as the ones stating constitutional violations (unless refuted by the State). And, of course, when the Brady Court cited Wilde as extending the due process test first enunciated in Mooney, ${ }^{334}$ it was speaking solely about suppression, which implicates the Due Process Clause, and not the denial of the right to counsel, which implicates the Sixth Amendment. ${ }^{335}$

The fact that Wilde was a case that was principally about the suppression of eyewitness statements before a defendant pleaded guilty bolsters the argument that it should be revitalized to recognize a clear right to evidence of innocence before pleading guilty. As noted, the Supreme Court itself as well as other courts and commentators have found that the Brady doctrine was merely an extension of the Mooney line of cases, with Brady simply making the good faith or bad faith of the State irrelevant. ${ }^{336}$ Given the limited nature of the Brady extension, it seems like the legitimacy of the Brady doctrine hinges on the existence of pre-existing precedent holding that the State's suppression of material exculpatory evidence can violate the Due Process Clause.

And yet, four of the six Supreme Court cases cited by the Brady Court - Mooney v. Holohan, Durley v. Mayo, Alcorta v. Texas, and Napue v. Illinois - solely dealt with the subornation of perjury and had nothing to do with the suppression of evidence. ${ }^{337}$ Meanwhile, a fifth case Pyle v. Kansas - dealt principally with the subornation of perjury338 and only secondarily with the suppression of evidence. 339 In this context, the importance of Wilde is apparent. As the only pre-Brady case based principally on the suppression of exculpatory evidence, it would seem to provide the heart of the Brady doctrine. Conversely, if Wilde is not seen as recognizing a due process right to exculpatory evidence, the

\footnotetext{
333 See supra Part IV.B.

334 Brady v. Maryland, 373 U.S. 83, 87 (1963).

335 See U.S. CONST. amend. VI ("In all criminal prosecutions, the accused shall enjoy the right ... to have the assistance of counsel for his defense.").

336 See supra notes 218-29 and accompanying text.

337 See Gershman, supra note 220, at 693, 693 n.36; see also United States v. Bagley, 473 U.S. 667, 679 n.8 (1985) ("In fact, the Brady rule has its roots in a series of cases dealing with convictions based on the prosecution's knowing use of perjured testimony.").

338 As noted, the Court found that Pyle's claims of subornation and suppression were supported by Pyle's exhibits, which solely related to his subornation claim.

339 See Gershman, supra note 220, at 693 n.38.
} 
Brady doctrine appears difficult to defend, given that the Brady Court itself acknowledged that it wasn't breaking much new ground.

And, indeed, other commentators have challenged the foundational weakness of the Brady doctrine. For instance, Professor Colin Starger has noted that "it is quite a leap to infer an affirmative duty to disclose exculpatory evidence from cases that imposed a negative prohibition on suborning perjury or allowing lies to stand uncorrected." 340 Meanwhile, Professor Eugene Cerruti has observed that on the eve of Brady "there was virtually no law requiring pretrial discovery by the defense of exculpatory material within the state's possession," with Mooney and its progeny dealing solely with subornation of perjury. ${ }^{341}$

The Supreme Court itself has even recognized the possible foundational weakness of the Brady doctrine. In Imbler v. Pachtman, the Court addressed the question of whether the test for qualified immunity differs depending on whether a prosecutor suppressed evidence or suborned perjury. ${ }^{342}$ While Justice White's concurrence would have drawn such a distinction, the majority found that "the distinction is not susceptible of practical application" because "[a] claim of using perjured testimony simply may be reframed and asserted as a claim of suppression of the evidence upon which the knowledge of perjury rested." 343 As support for this claim, the Court cited to its prior opinions "discussing the constitutional prohibitions against both practices," including Mooney v. Holohan, Alcorta v. Texas, and Brady v. Maryland. ${ }^{344}$ But this citation was incorrect because Mooney and Alcorta solely discussed the subornation of perjury and did not mention suppressed evidence. ${ }^{345}$

The reality is that Pyle v. Kansas and Wilde v. Wyoming were the only two pre-Brady Supreme Court cases dealing with the suppression of exculpatory evidence. ${ }^{346}$ This explains why, as noted, courts often cited

340 Colin Starger, Expanding Stare Decisis: The Role of Precedent in the Unfolding Dialectic of Brady v. Maryland, 46 Loy. L.A. L. REV. 77, 123 (2012).

341 Eugene Cerruti, Through the Looking-Glass at the Brady Doctrine: Some New Reflections on White Queens, Hobgoblins, and Due Process, 94 Ky. L.J. 211, 227 (20052006).

342 Imbler v. Pachtman, 424 U.S. 409, 431 n.34 (1976).

343 Id.

344 Id.

345 See supra notes 10-27, 55-68 and accompanying text.

346 Professor Gershman references Wilde and Pyle as two of the cases that the Brady Court extended to create the Brady doctrine but only identifies Pyle as a case involving the suppression of favorable evidence. See Gershman, supra note 220, at 693 ("In only one of those decisions [Pyle] did the Court cite the prosecutor's failure to disclose favorable evidence."). 
Wilde and Pyle in conjunction as the pre-Brady cases standing for the proposition that the suppression of favorable evidence can violate due process. $^{347}$ Since 1974, however, courts have only cited Pyle for this proposition. ${ }^{348}$ Pyle's continuing vitality ${ }^{349}$ provides support for the claim that Wilde should be resuscitated.

Standing alone, Wilde could be dismissed as a case in which the Supreme Court merely remanded a petitioner's claim that the State's suppression of exculpatory evidence violated the Due Process Clause and did not actually find such a violation. But a review of Pyle reveals the exact same factual context. Like Victor Wilde, Harry Pyle filed a pro se petition for writ of habeas corpus alleging the suppression of exculpatory evidence, and, like Wilde, Pyle merely received a remand. 350 Indeed, after Pyle was remanded, the Supreme Court of Kansas found no evidence that the State had suborned perjury or suppressed evidence ${ }^{351}$ while there is some indication that Wilde was given relief on remand. ${ }^{352}$

Finally, it is important to note that the Brady Court held that Pyle $v$. Kansas phrased the due process rule from Mooney v. Holohan "in broader terms." 353 In Mooney, the Court actually dismissed the defendant's case, finding that he had pleaded a plausible due process violation but failed to seek state habeas relief. ${ }^{354}$ Moreover, as noted, when Mooney did seek state habeas relief, the Supreme Court of California found no evidence of a due process violation. ${ }^{355}$ And yet, courts continue to cite Mooney to find due process violations. 356

\footnotetext{
347 See supra note 277 and accompanying text.

348 See supra note 278 and accompanying text.

349 See supra notes 240-244 and accompanying text.

350 See supra notes 28-37 and accompanying text.

351 Supra note 38 and accompanying text.

352 As noted, Wilde alleged, inter alia, that he was improperly given a "natural life" sentence instead of a sentence of twenty years to life. See supra Part IV.B. No court records exist indicating whether Wilde received habeas relief on remand. Victor Donald Wilde, however, was clearly released from prison because he later pleaded guilty to murder in Idaho, with the Court of Appeals of Idaho affirming his conviction in 1983. See State v. Wilde, 660 P.2d 73 (Idaho Ct. App. 1983). That opinion obliquely references the fact that Wilde "had previously served a prison sentence in Wyoming for another homicide." Id. at 74. Wilde's appellate counsel in Idaho has no recollection of whether Wilde was eventually given relief in his Wyoming case. Telephone Interview with Laird Stone, Wilde's former attorney (October 10, 2018).

353 See supra note 103 and accompanying text.

354 Supra notes 24-25 and accompanying text.

355 See supra note 26 and accompanying text.

356 See supra notes 233-238 and accompanying text.
} 
In conclusion, then, the continuing vitality of Pyle and Mooney means that there is no good reason to ignore Wilde. It is true that the Wilde Court merely remanded, but that was the same action taken by the Pyle Court and certainly no worse than the dismissal in Mooney. Because courts continue to cite Mooney and Pyle as illustrations of due process violations, ${ }^{357}$ they should do the same with Wilde. Therefore, unless Wilde has been repudiated, courts, including the Supreme Court, should resuscitate Wilde to find a right to evidence of innocence before pleading guilty that is part of the heart of the Brady doctrine.

This wouldn't be the first instance of such a resuscitation. In 1794, the Supreme Court issued its opinion in United States v. Yale Todd at a time when there was no official reporter, leading to the opinion being forgotten. ${ }^{358}$ Later, in its 1851 opinion in United States v. Ferreira, the Supreme Court rediscovered Yale Todd and recognized that it resolved "a question which was left in doubt by the opinions of the different judges." 359 The Ferreira Court then resuscitated Yale Todd by appending it to its opinion "in order that it may not be overlooked, if similar questions should hereafter arise." 360 If the Supreme Court were to revive Wilde, it would similarly be binding precedent on lower courts. ${ }^{361}$

The remaining question, however, is whether the Supreme Court impliedly repudiated Wilde in United States v. Ruiz.

\section{The Supreme Court Did Not RePudiate WiLDE IN RUIZ}

As noted, in United States v. Ruiz, the Supreme Court held that there is no pre-plea right to material impeachment evidence. ${ }^{362}$ The Ruiz Court did not explicitly reference Wilde, but Ruiz could be seen as an implied repudiation of Wilde if (1) Ruiz could be read in conjunction with other Supreme Court precedent as a rejection of a right to evidence of innocence before pleading guilty; or (2) Ruiz itself could be read as a rejection of a right to evidence of innocence before pleading guilty. The following two Sections will address these possibilities.

\footnotetext{
357 See supra notes 233-238, 240-244 and accompanying text.

358 See United States v. Ferreira, 54 U.S. 40, 52 (1851).

359 Id.

$360 \mathrm{Id}$.

361 See Stephen E. Sachs, The "Constitution in Exile" as a Problem for Legal Theory, 89 Notre DAmE L. REV. 2253, 2270 (2014) ("[O]ne might always discover a long-forgotten Supreme Court decision [such as Yale Todd] addressing a disputed point, which would then be precedent binding on lower courts.").

362 See supra notes 177-180 and accompanying text.
} 


\section{A. No Distinction Between Impeachment and Substantive Evidence}

As noted, some courts have taken a two-step approach to finding that Ruiz can be read in conjunction with other Supreme Court precedent as rejecting a right to evidence of innocence before pleading guilty. ${ }^{363}$ First, Ruiz held that there is no pre-plea right to material impeachment evidence. ${ }^{364}$ Second, the Supreme Court affirmed in United States $v$. Bagley that " $[\mathrm{t}]$ his Court has rejected any such distinction between impeachment evidence and exculpatory evidence." 365 Therefore, these courts conclude that the Ruiz Court's finding that there is no pre-plea right to material impeachment evidence means that there is no pre-plea right to material substantive evidence. ${ }^{366}$

These courts, however, are ignoring the limited nature of the Bagley Court's ruling. As noted, in Bagley, the Ninth Circuit held that the State's suppression of impeachment evidence required automatic reversal without a showing of materiality under Brady. ${ }^{367}$ The Supreme Court later reversed, holding that "[t]his Court has rejected any such distinction between impeachment evidence and exculpatory evidence." 368 The Bagley Court's use of the word "such" is important because it means the Supreme Court was merely saying that it had rejected any distinction between impeachment and substantive evidence in terms of Brady's materiality analysis. As one district court has noted, "[t]he 'any such distinction' referred to the lower court's conclusion that omission of impeachment information mandated an automatic reversal, whereas omission of exculpatory information did not require automatic reversal." 369 Therefore, "[t] he Court in Bagley did not categorically reject all distinctions between exculpatory and impeachment evidence." 370

This, of course, makes sense because the Supreme Court "has not treated exculpatory evidence and impeachment information as indistinguishable." ${ }^{771}$ Multiple examples can be found in the Federal Rules of Evidence ("FRE") adopted by the Supreme Court in 1972. For instance, a prior inconsistent statement by a witness that was not made

\footnotetext{
363 See supra notes 182-189 and accompanying text.

364 See supra notes $178-180$ and accompanying text.

365 United States v. Bagley, 473 U.S. 667, 676 (1985).

366 See supra note 184 and accompanying text.

367 See Bagley, 473 U.S. at 676.

368 Id. (emphasis added).

369 United States v. Nelson, 59 F. Supp. 3d 15, 21 (D.D.C. 2014).

370 Id.

371 Id.
} 
subject to the penalty of perjury is admissible under FRE 613 to impeach the witness but inadmissible as substantive evidence of the truth of the matter asserted. ${ }^{372}$ And evidence of a subsequent remedial measure is generally inadmissible as substantive evidence but potentially admissible as impeachment evidence under FRE 407.373 The Supreme Court has also created an "impeachment exception" to the exclusionary rule that allows illegally obtained evidence to be offered for impeachment, but not substantive, purposes. ${ }^{374}$

Therefore, the mere fact that the Bagley Court did not distinguish between impeachment evidence and substantive evidence in terms of materiality tells us little about whether the Supreme Court would distinguish between impeachment evidence and substantive evidence in terms of the applicability of the Brady doctrine in the pleading context. The last remaining question is thus whether the Ruiz Court itself conflated impeachment evidence and substantive evidence in this context.

\section{B. The Ruiz Court Did Not Repudiate Wilde}

In finding no pre-plea right to material impeachment evidence, the Supreme Court clearly distinguished a case like Ruiz from a case like Wilde. The Ruiz Court focused upon the extent to which recognizing a pre-plea right to material impeachment evidence would provide an additional safeguard for innocent defendants. ${ }^{375}$ In rejecting the defendant's concern that the lack of such a right would lead to innocent defendants pleading guilty, the Ruiz Court observed that the plea agreement offered to the defendant stated that "the Government will provide 'any information establishing the factual innocence of the defendant' regardless." 376 By making this observation, the Court acknowledged that the result would, or at least could, have been different if the State had withheld substantive evidence of innocence instead of impeachment evidence. ${ }^{377}$

372 See FED. R. EVID. 613; FED. R. EVID. 801(d)(1)(A) (allowing for the admission of prior inconsistent statements made subject to the penalty of perjury for substantive and impeachment purposes).

373 See FED. R. EvID. 407 (noting that evidence of a subsequent remedial measure is inadmissible for several substantive purposes but potentially admissible for impeachment purposes).

374 See James v. Illinois, 493 U.S. 307, 320 (1990).

375 See United States v. Ruiz, 536 U.S. 622, 631 (2002).

376 Id.

377 See, e.g., McCann v. Mangialardi, 337 F.3d 782, 788 (7th Cir. 2003) (finding that this language makes it "highly likely that the Supreme Court would find a violation of 
In finding no pre-plea right to material impeachment evidence, the Ruiz Court also focused on other factors that distinguish impeachment evidence from substantive evidence of innocence. The Ruiz Court noted that there is no pre-plea right to impeachment evidence because "the need for this information is more closely related to the fairness of a trial than to the voluntariness of the plea." 378 By concluding that impeachment evidence is "special" in relation to the fairness of trials, the Ruiz court implied that substantive evidence of innocence does relate to the voluntariness of pleas. ${ }^{379}$ In other words, if impeachment evidence is "special" in relation to the fairness of trials, this implies that substantive evidence in not specially connected to trials and that its suppression in connection with pleading can violate the Brady doctrine.

The Ruiz Court also observed that "[i]t is particularly difficult to characterize impeachment information as critical information of which the defendant must always be aware prior to pleading guilty given the random way in which such information may, or may not, help a particular defendant." 380 This particular difficulty relates to the fact that defendants (and often prosecutors) do not know whether particular witnesses will be critical or even called before the defendant pleads guilty. ${ }^{381}$ Conversely, there is no such difficulty in characterizing substantive evidence of innocence such as a video showing that an assault did not occur, exculpatory eyewitness statements, or DNA evidence. ${ }^{382}$

The Ruiz Court's reasoning makes clear that the Court did not definitely rule on a right to evidence of innocence before pleading guilty, meaning it should not be read as an implied repudiation of Wilde.

the Due Process Clause if prosecutors or other relevant government actors have knowledge of a criminal defendant's factual innocence but fail to disclose such information to a defendant before he enters into a guilty plea"); Russell D. Covey, PleaBargaining Law After Lafler and Frye, 51 DuQ. L. REV. 595, 604 (2013) (noting that, by using this language, the Ruiz Court "expressly declined to consider whether the same analysis applies to substantive evidence of factual innocence").

378 Ruiz, 536 U.S. at 633 (emphasis in original).

379 See, e.g., United States v. Lovato, Cr. No. 11-02416-JCH, 2012 WL 13076317, at * 1 n.l (D.N.M. Oct. 2, 2012) ("The government thus relies on Ruiz for the proposition that impeachment evidence 'is special in relation to the fairness of a trial,' and can be distinguished from exculpatory evidence which may be used to support a defendant's factual innocence.") (emphasis in original).

380 Ruiz, 536 U.S. at 630.

381 See id. ("The degree of help . . . will depend upon the defendant's own independent knowledge of the prosecution's potential case - a matter that the Constitution does not require prosecutors to disclose.").

382 See, e.g., Buffey v. Ballard, 782 S.E.2d 204, 221 (W. Va. 2015) (finding a Brady violation based on the State's pre-plea suppression of exculpatory DNA evidence). 
Moreover, "the Court in Ruiz used the terms 'exculpatory' and 'impeachment' separately, rather than as identical terms,"383 again invalidating any claim of an implied repudiation. Therefore, courts should view Wilde as a viable Supreme Court opinion holding that the right to evidence of innocence before pleading guilty is clearly established federal law.

\section{CONCLUSION}

In Brady v. Maryland, the Supreme Court held that the State has an affirmative obligation under the Due Process Clause to disclose material exculpatory evidence to defendants. ${ }^{384}$ In the wake of United States $v$. Ruiz, however, many courts have held that defendants have no pre-plea right to substantive evidence of innocence. ${ }^{385}$ Given that around $95 \%$ of convictions are secured through guilty pleas, ${ }^{386}$ such an interpretation of Brady means that few defendants are entitled to evidence of their innocence before being convicted. This statistic is significant because it is now clear that innocent defendants do plead guilty. Specifically, in 2015 and 2016, a total of 139 out of 314 DNA and non-DNA exonerees (44.26\%) had been convicted after guilty pleas. ${ }^{387}$

But courts finding no pre-plea right to substantive evidence of innocence are ignoring a key part of the foundation of the Brady doctrine. The Brady Court held that the Brady doctrine was an extension of six prior Supreme Court cases, four of which dealt solely with the subornation of perjury. ${ }^{388}$ That leaves two cases cited by the Brady Court that dealt with the suppression of exculpatory evidence: (1) Pyle v. Kansas, in which the Court remanded a claim that the State suppressed evidence of innocence before trial;389 and (2) Wilde $v$. Wyoming, in which the Court remanded a claim that the State suppressed evidence of innocence before a guilty plea. ${ }^{390}$ For years, courts cited these two cases in conjunction to conclude that the suppression of material exculpatory evidence violates Due Process

\footnotetext{
383 United States v. Nelson, 59 F. Supp. 3d 15, 21 (D.D.C. 2014).

384 See Brady v. Maryland, 373 U.S. 83, 87 (1963).

385 See supra notes 182-189, 196-209 and accompanying text.

386 See Padilla v. Kentucky, 559 U.S. 356, 372 (2010).

387 See NAT'L Registry OF EXONERATIONS, EXONERATIONS IN 2016 1-2 (2017), https://www.law.umich.edu/special/exoneration/Documents/Exonerations_in_2016.pdf; NAT'L Registry of EXONERATIONS, EXONERATIONS IN 20158 (2016), http://www.law. umich.edu/special/exoneration/Documents/Exonerations_in_2015.pdf.

388 See supra note 335 and accompanying text.

389 See supra notes 28-39 and accompanying text.

390 See supra notes 84-85 and accompanying text.
} 
Clause. ${ }^{391}$ But while Wilde has never been repudiated, it has fallen off the map ${ }^{392}$ while courts continue to cite Pyle for this proposition. ${ }^{393}$

By unearthing the pleadings in the Wilde case, this Article has established that Victor Donald Wilde's habeas petition primarily claimed that his guilty plea was induced by the State's suppression of exculpatory eyewitness statements. Therefore, by remanding in Wilde, the Supreme Court recognized a right to evidence before pleading guilty just as it recognized a right to evidence of innocence before trial by remanding in Pyle. Courts should therefore resuscitate Wilde to find a clear right to evidence of innocence before pleading guilty.

391 See supra note 277 and accompanying text.

392 See supra notes 269-286 and accompanying text.

393 See supra notes 239-244 and accompanying text. 